Soil Tillage, Conservation, and Management

\title{
Nitrogen mineralized in anaerobiosis as indicator of soil aggregate stability
}

\section{Camila Rivero $^{1,2}$ ｜ Santiago N. Tourn ${ }^{1} \quad$ Gisela V. García ${ }^{1,3}$ ｜ Cecilia C. Videla | Germán F. Domínguez $^{1} \quad$ Guillermo A. Studdert ${ }^{1}$ (i)}

${ }^{1}$ Facultad de Ciencias Agrarias, Univ. Nacional de Mar del Plata, Unidad Integrada Balcarce, Ruta Nacional 226 km 73,5, (B7620BKL) Balcarce, Buenos Aires, Argentina

${ }^{2}$ Consejo Nacional de Investigaciones Científicas y Técnicas, Ruta Nacional 226 km 73.5, (B7620BKL) Balcarce, Buenos Aires, Argentina

${ }^{3}$ Comisión de Investigaciones Científicas de la Provincia de Buenos Aires, Ruta Nacional 226 km 73.5, (B7620BKL) Balcarce, Buenos Aires, Argentina

\section{Correspondence}

Guillermo A. Studdert, Facultad de Ciencias Agrarias, Univ. Nacional de Mar del Plata, Unidad Integrada Balcarce, Ruta Nacional 226 km 73,5, (B7620BKL) Balcarce, Buenos Aires, Argentina.

Email: gastudde@mdp.edu.ar

Funding information

Fondo para la Investigación Científica y Tecnológica, Grant/Award Number: PICT 2012-1092; Universidad Nacional de Mar del Plata, Grant/Award Numbers: AGR537/17, AGR570/18; Instituto Nacional de Tecnología Agropecuaria, Grant/Award Number: PNCyO 1127032

\begin{abstract}
Monitoring soil health status is imperative to pursue sustainable agriculture. Aggregate stability (AS) is fundamental to define several soil functions and, therefore, physical soil health. The objectives of this work were to (i) evaluate the effect of contrasting cropping systems on AS, soil (SOC) and particulate (POC) organic carbon, and anaerobic nitrogen (AN) both in bulk soil and in macroaggregates (MA), and (ii) assess the relationship between AS and AN both in bulk soil and in MA to facilitate soil physical health monitoring. Aggregate stability, AN, SOC and POC were evaluated at three depths (0-5, 5-20, and 0-20 cm) in a Mollisol of the Southeastern Argentinean Pampas under a long-term experiment of cropping systems (crop-pasture rotations under conventional tillage [CT] and no-tillage [NT]). Bulk-soil SOC and POC contents and AN showed the effect of cropping systems, especially the effect of crop-pasture rotation and at $0-5 \mathrm{~cm}$ depth. However, NT did not lead to SOC sequestration except at $0-5 \mathrm{~cm}$ depth. In turn, pastures in the rotation and NT improved AS. Bulk-soil AN explained 75,41 , and $71 \%$ of AS at $0-5,5-20$, and $0-20 \mathrm{~cm}$ depths, respectively, and provides an indication of AS status. Instead, AN in MA did not explain bulk-soil AS changes as much as bulk-soil AN, except at $0-5 \mathrm{~cm}$ depth. Therefore, it is not worth determining AN in MA. However, routine bulk-soil AN determination at 0-20 cm depth by producers to diagnose nitrogen soil fertility would also provide an additional valuable indication of AS status.
\end{abstract}

\section{1 | INTRODUCTION}

Cropping systems should consider management practices that lead to maximizing crop productivity with minimum effect

\footnotetext{
Abbreviations: AN, nitrogen mineralized along a short anaerobic incubation; AS, aggregate stability; CMWD, change of mean weight aggregate diameter; CR, capillary re-wetting; CT, conventional tillage; L-MA, large macroaggregates (2.00-8.00 mm); MA, macroaggregate (>0.25 mm); MWD, mean weight aggregate diameter; NT, no-tillage; OC, organic carbon; POC, particulate soil organic carbon; SOC, soil organic carbon.
}

on soil ecosystem services (Powlson et al., 2011). Healthy soils are those that, despite the changes produced by agriculture, are able to maintain their functions in the agroecosystem according to their aptitude and the environmental conditions. Frequent evaluation of soil health is a primary condition when pursuing sustainable agriculture (Doran, 2002). Hence, early signals about the magnitude and orientation of changes due to agriculture would allow adjusting management practices to maintain or improve soil health. Therefore, the simpler, more sensitive, and cheaper the indicators to use, the higher the feasibility of frequent soil health monitoring by consultants and/or farmers (Romig, Garlynd, \& Harris, 1996). 
Particulate (POC) organic carbon (OC) is a labile fraction of soil OC (SOC) constituted by partially decomposed plant residues, fungi hyphae, spores, pollen grains, and animal debris (Gregorich, Beare, McKim, \& Skjemstad, 2006). Given its characteristics and its location within soil mass, POC presents, in general, rapid turnover and is very accessible to microorganisms (Christensen, 2001). Particulate OC is associated to aggregation mechanisms since it intervenes in the processes of formation and turnover of microaggregates $(0.05-0.25 \mathrm{~mm}, \mathrm{MI})$ and of formation and stabilization of macroaggregates ( $>0.25 \mathrm{~mm}, \mathrm{MA})$ (Gregorich et al., 2006; Six, Elliott, \& Paustian, 2000, 2004). On the other hand, POC is related to nutrient availability to crops given it is involved in the mineralization-immobilization of nitrogen (N) (Christensen, 2001; Six et al., 2000). The decrease of POC content in soil is associated to a reduction in soil functioning capacity and in soil resistance to degradation and soil resilience (Cambardella \& Elliott, 1992; Gregorich et al., 2006; Six, Bossuyt, Degryze, \& Denef, 2004). Particulate OC content is very sensitive to soil use and management practices (Cambardella \& Elliott, 1992; Domínguez, Diovisalvi, Studdert, \& Monterubbianesi, 2009) and its rapid change makes POC a good early indicator (Christensen, 2001) to monitor soil health. However, the determination of POC is somehow tedious and very time-consuming. For this reason, the technique is not always adopted by commercial soil laboratories or, if adopted, the cost is too high to help to encourage frequent monitoring (Diovisalvi, Studdert, Reussi-Calvo, Domínguez, \& Berardo, 2014). Hence, to favor and facilitate frequent soil health status evaluation, it would be important to identify other soil parameters as sensitive to soil use as POC but easier and simpler to determine.

The potentially mineralizable $\mathrm{N}$ is a fraction of soil organic $\mathrm{N}$ associated to changes produced by management practices on OC labile fractions (Domínguez et al., 2009; Gregorich et al., 2006; Soon, Haq, \& Arshad, 2007). Even though potentially mineralized $\mathrm{N}$ is sensitive to soil use and management, its determination requires long-lasting aerobic incubations. This makes potentially mineralized $\mathrm{N}$ unfeasible as a tool to diagnose $\mathrm{N}$ fertility and recommend fertilization (Echeverría, San Martín, \& Bergonzi, 2000). The ammonium $\mathrm{N}\left(\mathrm{NH}_{4}{ }^{+}-\mathrm{N}\right)$ mineralized along a short $(7 \mathrm{~d})$ anaerobic incubation (N mineralized in anaerobiosis, AN) (Keeney, 1982) has been proposed as a rapid and precise estimator of potentially mineralized N (Echeverría et al., 2000). The AN also relates closely to soil organic $\mathrm{N}$ content and gross $\mathrm{N}$ mineralization rate (Gregorutti, Novelli, Melchiori, Ormaechea, \& Caviglia, 2014; Videla, Pazos, Trivelin, Echeverría, \& Studdert, 2005) and with changes in SOC and POC (Domínguez et al., 2016; Gregorutti et al., 2014; Reussi-Calvo et al., 2014; Studdert, Domingo, García, Monterubbianesi, \& Domínguez, 2017). In the Southeastern Argentinean Pampas the AN is being used to adjust $\mathrm{N}$ fertility diagnosis for wheat (Triticum aestivum

\section{Core Ideas}

- Anaerobically mineralized nitrogen (AN) reflects cropping-system effects.

- Change in aggregate stability (AS) due to management correlates with AN change.

- AN could be used as a good indicator of AS and to help to monitor it.

- AN in macroaggregates is not as sensitive as bulksoil AN to indicate AS.

L.) and maize (Zea mays L.) (Orcellet, Reussi-Calvo, SainzRozas, Wyngaard, \& Echeverría, 2017; Reussi-Calvo, SainzRozas, Echeverría, \& Berardo, 2013, 2018; Sainz-Rozas, Calviño, Echeverría, Barbieri, \& Redolatti, 2008). Likewise, it has been shown that AN is sensitive enough to distinguish contrasting management situations (Cozzoli, Fioriti, Studdert, Domínguez, \& Eiza, 2010; García, Studdert, Domingo, \& Domínguez, 2016; Gregorutti et al., 2014; Studdert et al., 2017) and it has been proposed as a possible indicator of AS (Domínguez et al., 2016). Given it is simple and cheap to determine, and easily interpreted, and that its changes are associated with the changes in very many other soil parameters and properties, AN gathers several characteristics of those required for a soil health indicator (Domínguez et al., 2016; Doran, 2002; García et al., 2016).

Soil physical health is strongly related to aggregation and aggregate stability (AS) since they determine many other soil physical properties (i.e., pore geometry and stability, water infiltration, drainage, and retention) and is associated to several degradation processes (i.e., erosion, desertification, compaction) (Aparicio \& Costa, 2007) and to OC dynamics (Six et al., 2004). Soil OC, and particularly POC, plays a key role in defining aggregation and AS in most agricultural soils (Domínguez et al., 2016; Six et al., 2004). As well as SOC and POC (Quiroga \& Studdert, 2014), AS is very sensitive to the effect of agriculture (Aparicio \& Costa, 2007). However, it has been reported that the stability of MA would be more sensitive than bulk-soil AS to the changes produced by agriculture (Gregorutti et al., 2014; Puget, Chenu, \& Balesdent, 2000; Roldán, Studdert, Videla, San Martino, \& Picone, 2014; Six, Elliott, Paustian, \& Doran, 1998). Aggressive tillage (i.e., conventional tillage, CT) increases MA cycling rate and reduces its stability and bulk-soil AS. As well, tillage inhibits MI formation within MA and reduces SOC sequestration in the long term (Panettieri, Berns, Knicker, Murillo, \& Madejón, 2015, Six et al., 2004). On the other hand, no-tillage (NT) favors OC accumulation within aggregates and therefore, could lead to greater carbon sequestration in soil. Soils under NT generally show higher AS and a greater proportion of stable MA (Roldán et al., 2014; Sheehy, Regina, Alakukku, 


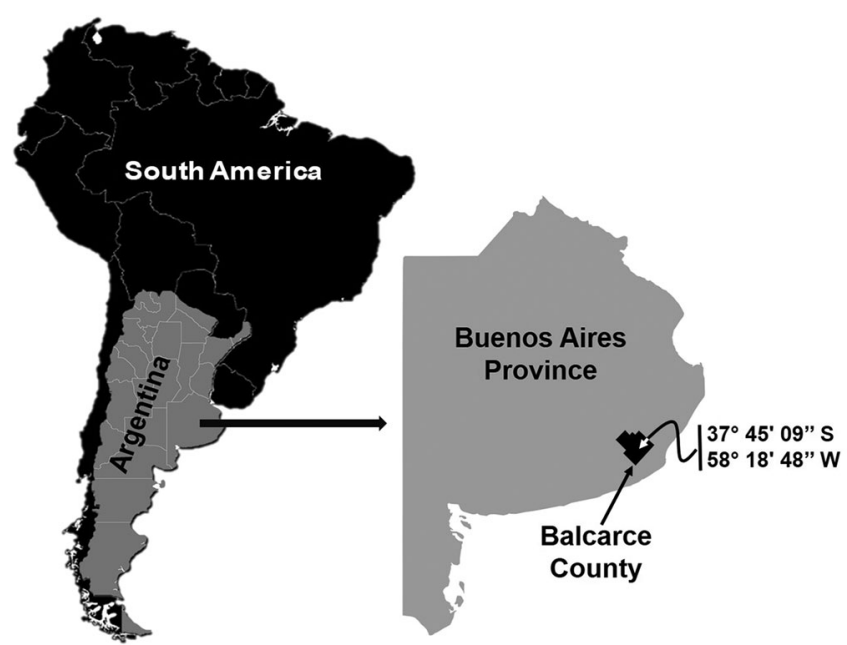

F I G URE 1 Location of the experiment

$\&$ Six, 2015) attributed to higher protection and stabilization of SOC within aggregates. Conversion of cropping systems under aggressive tillage into others with less soil disturbance intensity/frequency could benefit some aspects of soil functioning and integrity (Triplett \& Dick, 2008), but tillage is sometimes needed (Studdert et al., 2017). Early and simple soil health indicators could help to make decisions respect to when, where, how, and for how long soil could be tilled according to soil health status. Given its characteristics and its relationship with SOC and POC variation (Domínguez et al., 2016; García et al., 2016; Studdert et al., 2017), AN changes due to soil use and management would indicate changes in AS.

For Mollisols of the Southeastern Argentinean Pampas we hypothesized that: (i) changes of bulk-soil AN due to soil use and management is related to changes in bulk-soil AS, and (ii) changes in AN of MA is more strongly related to changes in bulk-soil AS. The objectives of this work were to (i) evaluate the effect of contrasting cropping systems on AS, SOC, POC, and AN both in bulk soil and in MA, and (ii) assess the relationship between AN both in bulk soil and in MA and AS and if it could contribute to facilitate soil physical health monitoring as compared to other indicators (i.e., SOC and POC).

\section{2 | MATERIALS AND METHODS}

\section{1 | Experimental site}

Soil samples were taken in the fall of 2014 from a long-term crop-pasture rotation experiment located at the experimental field of the Unidad Integrada Balcarce (Balcarce Integrated Unit), Balcarce, Buenos Aires, Argentina $\left(37^{\circ} 45^{\prime} 09^{\prime \prime} \mathrm{S}\right.$, $58^{\circ} 18^{\prime} 48^{\prime \prime} \mathrm{W} ; 138 \mathrm{~m}$ above sea level) (Figure 1). The climate in this area is classified as mesothermal subhumid-humid
TA B LE 1 Properties of an adjacent undisturbed soil (Domínguez et al., 2009)

\begin{tabular}{|c|c|c|c|c|}
\hline \multirow[b]{2}{*}{ Soil variable } & & \multicolumn{3}{|c|}{ Soil depth } \\
\hline & & $0-5 \mathrm{~cm}$ & $5-20 \mathrm{~cm}$ & $0-20 \mathrm{~cm}$ \\
\hline \multirow{3}{*}{$\begin{array}{l}\text { Particle size } \\
\text { distribution, } \\
\mathrm{g} \mathrm{kg}^{-1}\end{array}$} & Clay & - & - & 23.1 \\
\hline & Silt & - & - & 35.8 \\
\hline & Sand & - & - & 41.1 \\
\hline Organic $\mathrm{C}, \mathrm{g} \mathrm{kg}^{-1}$ & & 33.9 & 33.1 & 33.3 \\
\hline Organic $\mathrm{N}, \mathrm{g} \mathrm{kg}^{-1}$ & & 2.52 & 2.58 & 2.57 \\
\hline $\mathrm{pH}(1: 2.5$ in water $)$ & & 5.6 & 5.3 & 5.4 \\
\hline $\mathrm{CEC}, \mathrm{cmol} \mathrm{kg}^{-1}$ & & 26.4 & 26.7 & 26.6 \\
\hline $\mathrm{Na}^{+}, \mathrm{cmol} \mathrm{kg}^{-1}$ & & 0.3 & 0.3 & 0.3 \\
\hline $\mathrm{K}^{+}, \mathrm{cmol} \mathrm{kg}^{-1}$ & & 2.6 & 1.7 & 1.9 \\
\hline $\mathrm{Ca}^{++}, \mathrm{cmol} \mathrm{kg}^{-1}$ & & 12.6 & 12.1 & 12.2 \\
\hline $\mathrm{Mg}^{++}, \mathrm{cmol} \mathrm{kg}^{-1}$ & & 1.9 & 1.7 & 1.8 \\
\hline Base saturation, $\%$ & & 65.8 & 59.3 & 60.9 \\
\hline
\end{tabular}

(according to Thornthwaite classification) or as temperate humid without dry season (according to Köpen classification) (A.I. Irigoyen, personal communication, 1 December 2006). Median annual rainfall, mean annual potential evapotranspiration, and air temperature (1975-2014) are $950 \mathrm{~mm}, 952 \mathrm{~mm}$, and $14.1{ }^{\circ} \mathrm{C}$, respectively (source: weather station located $1000 \mathrm{~m}$ away from the experiment). The soil is a complex of a fine, mixed, thermic Typic Argiudoll (Soil Survey Staff, 2014), Mar del Plata Series (INTA, 1979), and a fine, illitic, thermic Petrocalcic Argiudoll (Soil Survey Staff, 2014), Balcarce Series (petrocalcic horizon below $0.7 \mathrm{~m}$ ) (INTA, 1979) with $2 \%$ slope (very low erosion). Soil complex surface horizon initial selected properties are shown in Table 1.

The experiment started in 1976 with different durations and frequencies of grass-based pastures combined with different cash-crop cropping periods under CT (see Studdert, Echeverría, \& Casanovas, 1997). In 1994, the experiment was modified. Table 2 shows the cropping systems (crop sequences and tillage systems) between 1994 and 2014. Tillage system was included as a variable with two levels: CT (moldboard plow, disk grade, field cultivator or vibro-cultivator) and NT. Grass-based pasture periods were set at 3 yr long and cash-crop sequence in the cropping periods was maizesoybean [Glycine $\max$ (L.) Merr.]-spring wheat. Pastures were not grazed nor cut to harvest aboveground biomass. The experiment was performed with a randomized complete block design and a split-plot treatment arrangement and three replications. Cropping systems (Table 2) were assigned to the main plots $\left(20 \mathrm{~m}\right.$ by $\left.35 \mathrm{~m}=700 \mathrm{~m}^{2}\right)$ and $\mathrm{N}$ fertilization of only cash crops $\left(0,60,120\right.$, and $\left.180 \mathrm{~kg} \mathrm{~N}^{-1}\right)$ was assigned to sub-plots $\left(10 \mathrm{~m}\right.$ by $\left.17.5 \mathrm{~m}=175 \mathrm{~m}^{2}\right)$. However, for this experiment, soil samples were taken only from the sub-plots with $60 \mathrm{~kg} \mathrm{~N} \mathrm{ha}^{-1}$. The crops received phosphorus fertilization at planting ( 5 to $20 \mathrm{~kg} \mathrm{Pha}^{-1}$ ) according to soil analysis. 
T A B L E 2 Crop sequence for each cropping system between 1994 and 2014

\begin{tabular}{|c|c|c|c|c|c|c|c|}
\hline \multirow[b]{2}{*}{ Year } & \multicolumn{7}{|c|}{ Cropping system ${ }^{\mathrm{a}}$} \\
\hline & $\overline{\mathbf{P P}}$ & 50NT & 50CT & $75 \mathrm{NT}$ & 75CT & 100NT & 100CT \\
\hline 1994 & $\mathrm{~Pa}$ & $\mathrm{~Pa}$ & $\mathrm{~Pa}$ & $\mathrm{~Pa}$ & $\mathrm{~Pa}$ & $\mathrm{M}(\mathrm{NT})$ & M \\
\hline 1996 & $\mathrm{~Pa}$ & $\mathrm{~Pa}$ & $\mathrm{~Pa}$ & $\mathrm{~Pa}$ & $\mathrm{~Pa}$ & W (NT) & $\mathrm{W}$ \\
\hline 1997 & $\mathrm{~Pa}$ & $\mathrm{M}(\mathrm{NT})^{\mathrm{b}}$ & M & $\mathrm{M}(\mathrm{NT})$ & M & $\mathrm{M}(\mathrm{NT})$ & M \\
\hline 2000 & $\mathrm{~Pa}$ & $\mathrm{~Pa}$ & $\mathrm{~Pa}$ & $\mathrm{M}(\mathrm{NT})$ & M & $\mathrm{M}(\mathrm{NT})$ & M \\
\hline 2001 & $\mathrm{~Pa}$ & $\mathrm{~Pa}$ & $\mathrm{~Pa}$ & $\mathrm{~S}(\mathrm{NT})$ & $\mathrm{S}$ & $\mathrm{S}(\mathrm{NT})$ & S \\
\hline 2002 & $\mathrm{~Pa}$ & $\mathrm{~Pa}$ & $\mathrm{~Pa}$ & $\mathrm{~W}(\mathrm{NT})$ & W & $\mathrm{W}(\mathrm{NT})$ & W \\
\hline 2003 & $\mathrm{~Pa}$ & $\mathrm{M}(\mathrm{NT})$ & M & $\mathrm{M}(\mathrm{NT})$ & M & $\mathrm{M}(\mathrm{NT})$ & M \\
\hline 2007 & $\mathrm{~Pa}$ & $\mathrm{~Pa}$ & $\mathrm{~Pa}$ & $\mathrm{~Pa}$ & $\mathrm{~Pa}$ & $\mathrm{~S}(\mathrm{NT})$ & $\mathrm{S}$ \\
\hline 2008 & $\mathrm{~Pa}$ & $\mathrm{~Pa}$ & $\mathrm{~Pa}$ & $\mathrm{~Pa}$ & $\mathrm{~Pa}$ & W (NT) & $\mathrm{W}$ \\
\hline 2009 & $\mathrm{~Pa}$ & $\mathrm{M}(\mathrm{NT})$ & $\mathrm{M}$ & $\mathrm{M}(\mathrm{NT})$ & M & $\mathrm{M}(\mathrm{NT})$ & M \\
\hline 2010 & $\mathrm{~Pa}$ & S (NT) & $\mathrm{S}$ & $\mathrm{S}(\mathrm{NT})$ & $\mathrm{S}$ & $\mathrm{S}(\mathrm{NT})$ & $\mathrm{S}$ \\
\hline 2011 & $\mathrm{~Pa}$ & $\mathrm{~W}(\mathrm{NT})$ & W & W (NT) & $\mathrm{W}$ & W (NT) & $\mathrm{W}$ \\
\hline 2012 & $\mathrm{~Pa}$ & $\mathrm{~Pa}$ & $\mathrm{~Pa}$ & $\mathrm{M}(\mathrm{NT})$ & M & $\mathrm{M}(\mathrm{NT})$ & M \\
\hline 2013 & $\mathrm{~Pa}$ & $\mathrm{~Pa}$ & $\mathrm{~Pa}$ & $\mathrm{~S}(\mathrm{NT})$ & $\mathrm{S}$ & $\mathrm{S}(\mathrm{NT})$ & S \\
\hline $2014^{c}$ & $\mathrm{~Pa}$ & $\mathrm{~Pa}$ & $\mathrm{~Pa}$ & $\mathrm{~W}(\mathrm{NT})$ & W & $\mathrm{W}(\mathrm{NT})$ & W \\
\hline SIIm ${ }^{d}$ & 1.00 & 0.76 & 0.76 & 0.65 & 0.65 & 0.50 & 0.50 \\
\hline
\end{tabular}

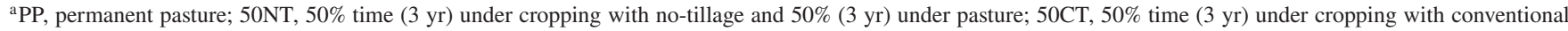
tillage and 50\% (3 yr) under pasture; 75NT, 75\% time (9 yr) under cropping with no-tillage and $25 \%$ ( $3 \mathrm{yr}$ ) under pasture; $75 \mathrm{CT}$, $75 \%$ time (9 yr) under cropping with conventional tillage and 25\% (3 yr) under pasture; 100NT, continuous cropping under no-tillage; 100CT, continuous cropping under conventional tillage; M, maize; S, soybean; W, wheat.

${ }^{b}$ Indicates the tillage system is no-tillage.

${ }^{\mathrm{c}}$ Soil sampling year.

${ }^{\mathrm{d} S I I m}$, sequence intensification index on a monthly basis (Novelli, Caviglia, \& Piñeiro, 2017).

\section{2 | Soil sampling and analytical determinations}

Soil sampling was done in the fall of 2014 (Table 2). Samples were taken with a shovel at $0-5$ and $5-20 \mathrm{~cm}$ depths with five subsamples per sub-plot to form a composite sample. Soil moisture at sampling was close to field capacity. Only the central part of the soil extracted with the shovel was it recovered from each subsample to avoid collecting aggregates disturbed by sampling. Fresh samples were carefully passed through an $8.00-\mathrm{mm}$ sieve (Six et al., 1998), oven-dried at $40^{\circ} \mathrm{C}$ and stored until analysis.

Besides, composite soil samples (5 subsamples per experimental unit) were taken at two depths $(0-5 \mathrm{~cm}$ and 5-20 cm) with a $4.5-\mathrm{cm}$-diameter tubular sampler. Soil samples were dried at $40^{\circ} \mathrm{C}$ until constant weight and ground to pass a 2.00-mm sieve and stored for analysis. Recognizable crop residues and roots retained on the $2.00-\mathrm{mm}$ sieve, were eliminated.
Aggregate size distribution was determined on the samples taken with the shovel according to Six et al. (1998). Briefly, two 100-g aliquots of dry soil from each sample sieved through 8.00-mm sieve, were re-wetted. One of those aliquots was capillary re-wetted (CR) during $24 \mathrm{~h}$ at room temperature up to approximately field capacity. Capillary re-wetted aggregates were then submerged in water just before sieving beginning. The other soil aliquot was rapidly re-wetted by submersion of dry aggregates in water. After $5 \mathrm{~min}$ of submersion, both CR aliquots and rapidly re-wetted aliquots were successively wet-sieved through different sieves: $2.00 \mathrm{~mm}$ (to separate large MA [L-MA], >2.00 mm), $0.25 \mathrm{~mm}$ (to separate small MA, $0.25-2.00 \mathrm{~mm}$ ), and $0.05 \mathrm{~mm}$ (to separate MI, $0.05-0.25 \mathrm{~mm}$ ). Fine fraction content (clay+silt, $<0.05 \mathrm{~mm}$ ) was calculated by difference. Sievings were done with an apparatus built ad hoc (R. and G. Domínguez, Pasteur, Argentina) to get $503-\mathrm{cm}$-run up and down oscillations during 2 min for each sieving. After sieving, aggregates were back-washed from the sieve in plastic recipients and let to 
settle after the addition of $2 \mathrm{ml}$ of calcium chloride $\left(\mathrm{CaCl}_{2}\right)$ $2 \mathrm{~N}$ solution. When the supernatant was clear, it was removed with a vacuum pump and the recipients were taken to an oven at $50^{\circ} \mathrm{C}$ until constant weight. Dry soil was weighed and stored.

Mean weight aggregate diameter (MWD, $\mathrm{mm}$ ) was determined for aggregate size distributions after each re-wetting procedure with the following equation:

$$
\mathrm{MWD}=\sum_{i=1}^{n=4} X_{i} * W_{i}
$$

where $i$ is each aggregate size fraction, $n$ is the number of aggregate size fractions including the fine fraction, $X_{i}$ is the mean diameter $(\mathrm{mm})$ of the $i$-th aggregate size fraction calculated as the average between the mesh size of the sieve from where the aggregates were recovered and the mesh size of the immediately upper sieve, and $W_{i}$ is the proportion of soil mass of the $i$-th aggregate size. Aggregate stability was calculated as change of MWD (CMWD, mm), calculated as the difference between MWD after CR and MWD after rapid rewetting. Change of MWD is the inverse of AS and, therefore, the higher CMWD, the lower AS. Given $95.9 \%$ of sand fraction was very fine $(0.05-0.10 \mathrm{~mm})$ and $2.8 \%$ was fine $(0.10$ $0.25 \mathrm{~mm}$ ) sand (data not shown; S.N. Tourn, doctoral dissertation, unpubl. data), the correction of the proportion of each aggregate size fraction by the proportion of free sand with the same size as the aggregates in the fraction (Six et al., 2000), was not done as indicated by Yamashita, Flessa, John, Helfrich, and Ludwig (2006).

Aliquots of ground (sieved through 2.00-mm sieve taken with the tubular sampler) dry bulk soil and of dry L-MA and small MA obtained by sieving after CR of samples taken with the shovel, were re-ground with mortar and pestle and analyzed for $\mathrm{AN}$ ( $\mathrm{mg} \mathrm{NH}_{4}{ }^{+}-\mathrm{N} \mathrm{kg}^{-1}$ ). Nitrogen mineralized in anaerobiosis was determined through a short anaerobic incubation (Keeney, 1982) of $5 \mathrm{~g}$ of dry re-ground soil in test tubes ( $150 \mathrm{~mm}$ by $16 \mathrm{~mm}$ ). Tube volume was completed with deionized water. The tubes were hermetically capped providing all air bubbles were removed. Then they were incubated for $7 \mathrm{~d}$ at $40^{\circ} \mathrm{C}$. At the end of the incubation, $15.0 \mathrm{ml}$ of $4 \mathrm{M}$ potassium chloride $(\mathrm{KCl})$ and $0.2-0.3 \mathrm{~g}$ of calcined magnesium oxide $(\mathrm{MgO})$ were added, and then, $\mathrm{NH}_{4}{ }^{+}-\mathrm{N}$ was determined by steam distillation (Keeney \& Nelson, 1982) directly on the resulting soil suspension (Echeverría et al., 2000). The same analytical procedure was used to determine $\mathrm{NH}_{4}{ }^{+}-\mathrm{N}$ content of soil before incubation to subtract it from $\mathrm{NH}_{4}{ }^{+}-\mathrm{N}$ after incubation. Initial $\mathrm{NH}_{4}{ }^{+}-\mathrm{N}$ was always low and not different among management situations both for bulk soil and L-MA and small MA (data not shown).

Soil OC and POC concentrations $\left(\mathrm{g} \mathrm{C} \mathrm{kg}^{-1}\right)$ both of bulk soil and of L-MA and small MA after CR were determined. Briefly, SOC was determined on the same re-ground soil samples as AN by wet combustion with maintenance of the oxi- dation reaction temperature $\left(120^{\circ} \mathrm{C}\right)$ for $90 \mathrm{~min}$ (Schlichting, Blume, \& Stahr, 1995). Particle-size fractionation was performed by wet-sieving through a $0.05-\mathrm{mm}$ sieve of re-ground and dispersed soil aliquots (Cambardella \& Elliott, 1992). Organic carbon concentration was determined as described above on soil fraction that passed the sieve $(<0.05 \mathrm{~mm})$ to determine $\mathrm{OC}$ associated to silt and clay $\left(\mathrm{g} \mathrm{C} \mathrm{kg}^{-1}\right)$. Particulate $\mathrm{OC}\left(\mathrm{g} \mathrm{C} \mathrm{kg}^{-1}\right)$ concentration was calculated by subtracting associated OC from SOC (Cambardella \& Elliott, 1992). Mean weight diameter, CMWD, AN, SOC, associated OC, and POC were also calculated for the arable layer $(0-20 \mathrm{~cm}$ depth) as a weigh average between $0-5$ and 5-20 cm depths.

\section{3 | Statistical analysis}

Response variables were analyzed for each depth (0-5, $5-20$, and $0-20 \mathrm{~cm}$ ) and re-wetting procedure (CR and rapid re-wetting) through analysis of variance with a mixed linear model. Cropping system was the fixed effect and block, the random effect. All mean comparisons were performed with the Tukey test. The relationships between variables were evaluated through linear correlation (Pearson) and regression analyses or through nonlinear (linear-plateau) regression analysis. Statistical analyses were performed with the package "Rcmdr" of the R statistical system (R Development Core Team, 2010). The significance level for all tests of hypothesis and mean comparisons, was set at $5 \%$.

\section{3 | RESULTS AND DISCUSSION}

\section{1 | Bulk-soil SOC and POC contents and AN}

Table 3 shows bulk-soil SOC and POC contents and AN at 0-5, 5-20, and 0-20 cm depths. Differences in SOC, POC, and AN among cropping systems were highly significant $(P<.01)$ at all three depths. As expected for this type of soils in the Southeastern Argentinean Pampas (Diovisalvi et al., 2014; Domínguez et al., 2009, 2016; Studdert et al., 2017), differences among treatments in SOC were mainly due to differences in POC given there were no differences among cropping systems in associated OC (data not sown). Likewise, AN showed a highly significant $(P<.01)$ positive correlation with both SOC $(r=0.83, r=0.65$, and $r=0.78$ at $0-5$, $5-20$, and 0-20 cm depths, respectively) and POC $(r=0.90$, $r=0.59$, and $r=0.86$, respectively), in coincidence with many authors (Domínguez et al., 2009, 2016; Reussi-Calvo et al., 2014; Soon et al., 2007).

Permanent pasture for $20 \mathrm{yr}$ (PP, Table 2) showed the highest SOC and POC contents and the highest AN (Cozzoli et al., 2010; Ernst \& Siri-Prieto, 2009; Franzluebbers, Sawchik, \& Taboada, 2014; Videla et al., 2005) at all three depths. Likewise, in agreement with Ernst and Siri-Prieto (2009), 
T A B L E 3 Soil (SOC) and particulate (POC) organic carbon, and ammonium nitrogen mineralized in anaerobiosis (AN) of bulk soil at three depths and under different cropping systems

\begin{tabular}{|c|c|c|c|c|}
\hline \multirow{2}{*}{$\begin{array}{l}\text { Depth } \\
\text { cm }\end{array}$} & \multirow[b]{2}{*}{ Cropping system ${ }^{\mathrm{a}}$} & \multirow{2}{*}{$\frac{\text { SOC }}{\mathrm{g} \mathrm{kg}^{-1}}$} & \multirow[t]{2}{*}{ POC } & \multirow{2}{*}{$\frac{\mathrm{AN}}{\mathrm{mg} \mathrm{kg}^{-1}}$} \\
\hline & & & & \\
\hline \multirow[t]{4}{*}{$0-5$} & PP & $40.7(0.6)^{b} a^{c}$ & $17.5(0.7) \mathrm{a}$ & $144.2(10.9) \mathrm{a}$ \\
\hline & $50 \mathrm{CT}$ & $34.4(0.1) b$ & $8.5(0.4) \mathrm{c}$ & $78.8(1.9) \mathrm{b}$ \\
\hline & $75 \mathrm{NT}$ & $35.9(0.4) b$ & $11.6(0.1) b$ & $122.7(5.2) \mathrm{a}$ \\
\hline & $100 \mathrm{CT}$ & $27.6(0.3) \mathrm{c}$ & $3.1(0.2) \mathrm{d}$ & $55.5(3.9) \mathrm{b}$ \\
\hline \multirow[t]{4}{*}{$5-20$} & PP & $32.2(0.5) \mathrm{a}$ & $8.0(0.3) \mathrm{a}$ & $76.6(1.2) \mathrm{a}$ \\
\hline & $50 \mathrm{NT}$ & $29.4(0.3) b c$ & $5.9(0.8) \mathrm{abc}$ & $61.6(3.8) \mathrm{ab}$ \\
\hline & $50 \mathrm{CT}$ & $30.6(0.4) \mathrm{ab}$ & $6.8(0.5) \mathrm{ab}$ & $58.9(3.2) \mathrm{bc}$ \\
\hline & $100 \mathrm{CT}$ & $26.6(0.5) \mathrm{d}$ & $4.0(0.6) b c$ & $49.9(1.4) b c$ \\
\hline \multirow[t]{7}{*}{$0-20$} & $\mathrm{PP}$ & $34.3(0.5) \mathrm{a}$ & $10.4(0.4) \mathrm{a}$ & $93.5(2.8) \mathrm{a}$ \\
\hline & $50 \mathrm{NT}$ & $31.9(0.3) \mathrm{b}$ & $8.4(0.5) \mathrm{ab}$ & $77.4(3.7) \mathrm{ab}$ \\
\hline & $50 \mathrm{CT}$ & $31.5(0.3) b$ & $7.2(0.3) b$ & $63.9(2.8) \mathrm{bc}$ \\
\hline & $75 \mathrm{NT}$ & $31.8(0.5) b$ & $7.8(0.7) b$ & $69.7(5.5) \mathrm{b}$ \\
\hline & $75 \mathrm{CT}$ & $27.5(0.4) \mathrm{c}$ & $3.6(0.3) \mathrm{c}$ & $47.9(3.0) \mathrm{c}$ \\
\hline & $100 \mathrm{NT}$ & $28.6(0.5) \mathrm{c}$ & $6.7(0.5) b$ & $76.8(1.4) \mathrm{b}$ \\
\hline & $100 \mathrm{CT}$ & $26.9(0.3) \mathrm{c}$ & $3.8(0.4) \mathrm{c}$ & $51.3(2.0) \mathrm{c}$ \\
\hline
\end{tabular}

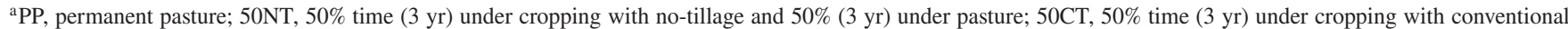
tillage and 50\% (3 yr) under pasture; 75NT, 75\% time (9 yr) under cropping with no-tillage and 25\% (3 yr) under pasture; 75CT, 75\% time (9 yr) under cropping with conventional tillage and 25\% (3 yr) under pasture; 100NT, continuous cropping under no-tillage; 100CT, continuous cropping under conventional tillage.

${ }^{\mathrm{b}}$ Numbers between parentheses are standard errors of the mean.

${ }^{\mathrm{c}}$ Values followed by a common letter within each depth are not significantly different $(P<.05)$ among cropping systems.

Studdert et al. (1997), and Panettieri, Rumpel, Dignac, and Chabbi (2017) respect to the effect of alternation of short periods under pasture and under cropping, 2 yr under pasture after $3 \mathrm{yr}$ of cropping (i.e., 50NT, and 50CT, Table 2) led to higher $\mathrm{SOC}, \mathrm{POC}$, and AN in the arable layer than most of the other cropping systems, but not as high as under PP (Table 3). At 0-20 cm depth SOC, POC, and AN under 50NT and 50CT were significantly lower than under PP. However, SOC, POC, and $\mathrm{AN}$ at $0-5 \mathrm{~cm}$ depth were significantly higher under PP and 50NT than under 50CT and not different between them. On the other hand, under cropping (i.e., 75NT, 75CT, 100NT, and $100 \mathrm{CT}$, Table 2), treatments with NT showed significantly higher SOC, POC, and AN at $0-5 \mathrm{~cm}$ depth than those under CT (Table 3). In turn, in the arable layer $(0-20 \mathrm{~cm}$ depth), SOC, POC, and AN tended to be higher under NT (i.e., $75 \mathrm{NT}$ and 100NT) than under CT (i.e., $75 \mathrm{CT}$ and $100 \mathrm{CT}$ ), in most cases significantly (Table 3 ). The strong stratification of soil organic fraction associated to pastures (Ernst \& SiriPrieto, 2009; Franzluebbers et al., 2014; Lemaire, Franzluebbers, de Faccio Carvalho, \& Dedieu, 2014) (PP, 50NT, and 50CT, Table 3) and NT (Franzluebbers, 2002; Powlson et al., 2014) (75NT and 100NT, Table 3) is expected to improve soil functioning due to the role of the uppermost soil layer in defining several soil functions and processes (Franzluebbers, 2002).

Continuous pasture or pasture periods rotated with cash crops improve SOC because of pasture dense root systems, the carbon returned to the soil through aboveground biomass litter, and the reduction of tillage intensity (Cates, Ruark, Hudtcke, \& Posner, 2016; Haynes, 1999; Six et al., 2004; Studdert et al., 1997). Besides, the higher the frequency and/or duration of pasture periods the longer the soil is covered by live plants and colonized/explored by active roots, and the more efficient is the use of available resources and inputs (Caviglia et al., 2019; Hochman et al., 2013; Novelli et al., 2017). These are indubitable advantages of the ecological agriculture intensification to improve soil health (i.e., soil functioning) and the provision of ecosystem services (Lemaire et al., 2014; Powlson et al., 2011). Something similar could be expected from NT because of soil cover by residues and the reduction of tillage intensity (Triplett \& Dick, 2008).

In this experiment NT did not lead to the complete restoration of soil organic matter in the whole arable layer despite 
SOC content was, in general, higher than under CT (Table 3). This agrees with Domínguez et al. (2016) and Studdert et al. (2017) who reported that neither SOC nor POC or AN in the arable layer, except at $0-5 \mathrm{~cm}$ depth, of similar soils were different between continuous cropping under $\mathrm{CT}$ and under NT (15 and $11 \mathrm{yr}$, respectively). They showed that at $0-20 \mathrm{~cm}$ depth both SOC and POC and AN decreased along the period under cropping at the same rate either under CT or NT. In our experiment, SOC at $0-20 \mathrm{~cm}$ depth at the beginning of the experiment (1976, after a long pasture period) had been $37.2 \mathrm{~g} \mathrm{~kg}^{-1}$ whereas at the beginning of the phase of the experiment analyzed in this paper (1994, after $18 \mathrm{yr}$ of cropping under CT, Table 2) it was approximately $30.4 \mathrm{~g} \mathrm{~kg}^{-1}$ (Studdert et al., 1997). Soil OC contents in 2014 for 50CT, 75CT, and $100 \mathrm{CT}$ averaged were $28.6 \mathrm{~g} \mathrm{~kg}^{-1}$ (Table 3). On the other hand, SOC contents in 2014 for 50NT, 75NT, and 100NT averaged $30.8 \mathrm{~g} \mathrm{~kg}^{-1}$ (Table 3). Therefore, despite SOC content in 1994 was low (Puget \& Lal, 2005), OC sequestration in the arable layer under NT was negligible even when cropping was rotated with pastures (Ernst, Dogliotti, Cadenazzi, \& Kemanian, 2018). However, 50NT and 75NT showed a slight increase in SOC at $0-20 \mathrm{~cm}$ depth along the $20 \mathrm{yr}$ analyzed. It is worth noting that a 2 -yr pasture period after a cropping period under NT (i.e., 50NT) or CT (i.e., 50CT) was not enough to increase $\mathrm{SOC}, \mathrm{POC}$, and $\mathrm{AN}$ at $0-20 \mathrm{~cm}$ depth up to the level of PP (Table 3). However, a 2-yr pasture period after a cropping period under CT (i.e., 50CT) increased SOC, POC, and AN above 75CT (i.e., $5 \mathrm{yr}$ of cropping after a pasture, Table 2) and 100CT (i.e., continuous cropping, Table 2) levels. Nitrogen mineralized in anaerobiosis under $75 \mathrm{CT}$ and 100CT was very close to the threshold of response to $\mathrm{N}$ fertilization (i.e., $\mathrm{AN}=48 \mathrm{mg} \mathrm{kg}^{-1}$, Sainz-Rozas et al., 2008) whereas the rest of the treatments were well above it (Table 3).

\section{2 | Aggregate size distribution and aggregate stability}

Figure 2 shows MWD after CR and after rapid re-wetting. As expected, aggregate size was smaller after rapid re-wetting (Figure 2b) than after CR (Figure 2a). When aggregates are re-wetted capillary (i.e., CR) water enters slowly into them and air within pores is displaced without generating internal pressures (Cambardella \& Elliott, 1993). Therefore, when soil is water-sieved after CR aggregates resist better the disruption stress because they are less exposed to internal forces and their stability is maximum when water content is close to field capacity (Hofman \& de Leenheer, 1975). On the other hand, when dry aggregates are re-wetted by sudden submersion (i.e., rapid re-wetting), water enters the pores abruptly trapping and compressing air within them. Thus, compressed air generates internal forces that, depending on the level of aggregation forces, may lead to aggregate slaking and/or make them prone to slaking when water sieved (Cambardella \& Elliott, 1993). Whenever soil condition means weak aggregation forces aggregates are more exposed to breaking off when sieved in water both after CR and, especially, after rapid re-wetting. The lowest MWD $(P<.05)$ was shown by 75CT and 100CT (Table 2) at all three depths and for both re-wetting procedures (Figure 2). Cropping systems under cropping with NT (i.e., 75NT and 100NT) showed significantly higher MWD than the corresponding cropping systems under CT (i.e., 75CT and 100CT), particularly after rapid rewetting. On the other hand, cropping systems under pasture at sampling (i.e., PP, 50NT, and 50CT, Table 2) showed higher MWD than the other treatments at all three depths and after both re-wetting procedures (Figure 2). The highest MWD $(P<.05)$ was shown by PP.

Figure 2c shows CMWD at all three depths. In general, most cropping systems showed significantly higher CMWD (i.e., lower AS) than PP at all three depths. Fibrous, dense, and extensive root systems associated with grass-based pastures lead to aggregate formation and stabilization (Franzluebbers et al., 2014; Haynes, 1999). Likewise, cropping systems under NT (i.e., 50NT, 75NT, and 100NT, Table 2) showed a trend toward lower CMWD than those under CT (i.e., 50CT, 75CT, and 100CT, Table 2), especially at $0-5 \mathrm{~cm}$ depth (Roldán et al., 2014; Sheehy et al., 2015; Six et al., 2004). In the uppermost layer, cropping systems under NT showed CMWD not different from PP and significantly lower than the corresponding treatments under CT. No-tillage did not lead to the complete restoration of organic matter despite the higher organic matter content than under CT (Table 3) but, in turn, it did lead to higher AS (Figure 2) as indicated by several authors (Panettieri et al., 2015; Roldán et al., 2014; Sheehy et al., 2015; Six et al., 2004). On the other hand, CMWD shown by 50NT and $50 \mathrm{CT}$ was lower (not always significantly) than the rest of the cropping systems under NT and CT, respectively, especially at $0-5 \mathrm{~cm}$ depth (Figure $2 \mathrm{c}$ ), but higher than PP (except at $0-5 \mathrm{~cm}$ depth comparing PP with 50NT). This confirms that introducing short pasture periods in crop rotations helps to restore soil aggregation and stabilization affected along cropping periods (Ernst \& Siri-Prieto, 2009; Haynes, 1999; Panettieri et al., 2017; Studdert et al., 1997), but it is not enough to restore AS in the arable layer. Tillage affects aggregate re-cycling and stabilization (Six et al., 2004) but cropping periods under NT could also affect aggregation (Roldán et al., 2014) probably due to a reduced input of carbon through residues. A 2-yr pasture period was not enough to restore AS below the surface $5 \mathrm{~cm}$. Both 50NT and 50CT showed significant higher CMWD than PP both at 5-20 $\mathrm{cm}$ and 0-20 cm depths but with no significant difference between them (Figure 2c).

It has been frequently reported that bulk-soil AS is determined by the stability of MA that is strongly influenced by soil use (Sheehy et al., 2015; Six et al., 2004) and is more 

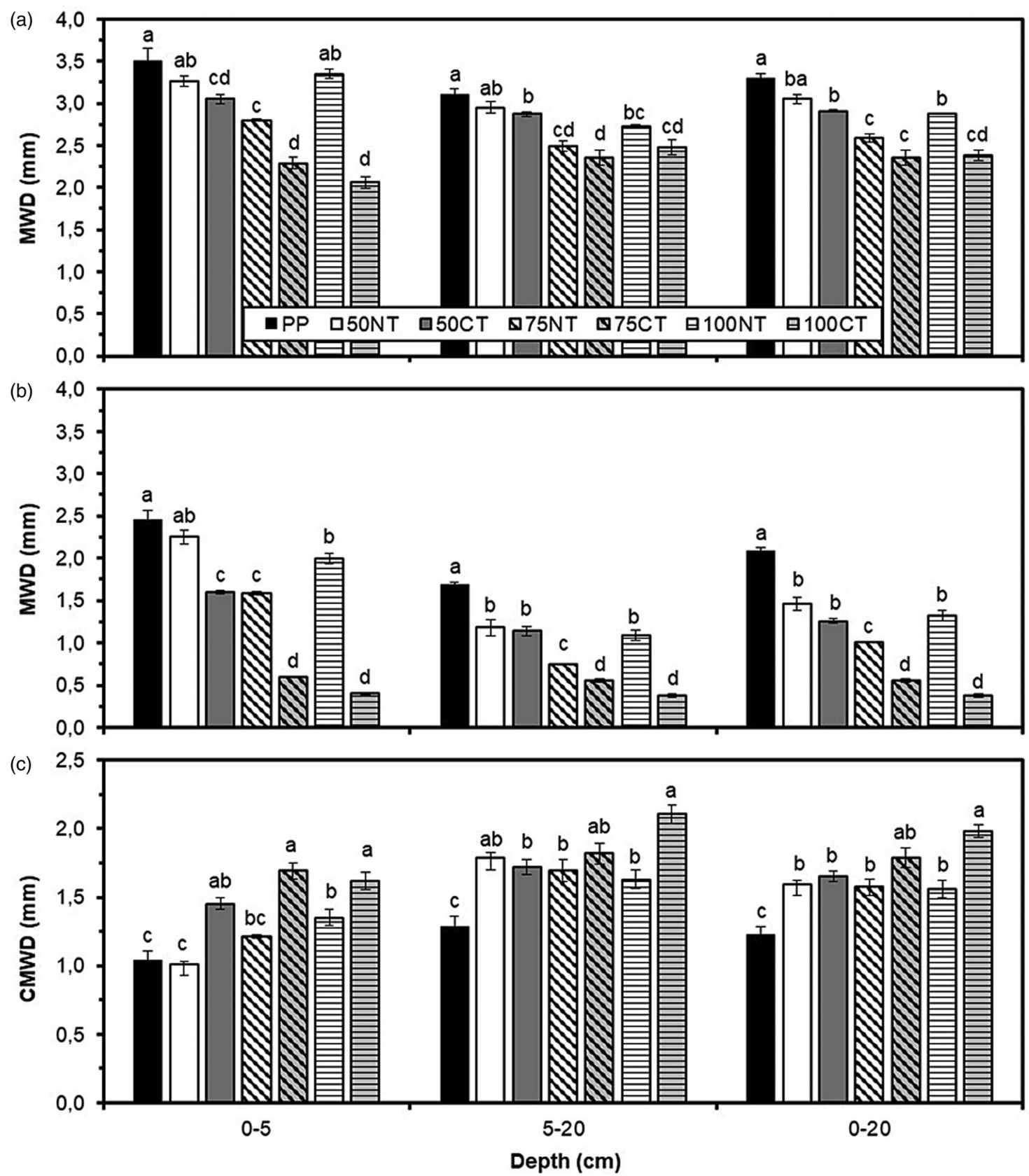

F I G U R E 2 Aggregate mean weight diameter (MWD) after capillary re-wetting (a) and rapid re-wetting (b) and change of MWD (CMWD) (c) for each cropping system and three soil depths. Vertical bars in each column indicate standard error of the mean. Different letters indicate significant differences $(P<.05)$ among cropping systems within depths. PP, permanent pasture; 50NT, 50\% time (3 yr) under cropping with no-tillage and 50\% (3 yr) under pasture; 50CT, 50\% time (3 yr) under cropping with conventional tillage $50 \%$ ( 3 yr) under pasture; $75 \mathrm{NT}$, $75 \%$ time ( $9 \mathrm{yr}$ ) under cropping with no-tillage and 25\% (3 yr) under pasture; 75CT, 75\% time (9 yr) under cropping with conventional tillage and $25 \%$ ( $3 \mathrm{yr}$ ) under pasture; $100 \mathrm{NT}$, continuous cropping under no-tillage; 100CT, continuous cropping under conventional tillage

sensitive to the effect of management practices than bulk-soil AS (Puget et al., 2000). Table 4 shows the change of aggregate fraction masses between sieving after rapid re-wetting and after CR. Differences in the change of fine fraction mass were not significant among cropping systems and very low at all three depths. This is in coincidence with Roldán et al. (2014) who had reported that MI of similar soils in the Southeastern Argentinean Pampas under contrasting management (continuous cropping under CT and NT) showed very low disruptions on water-sieving and, therefore, resulting fine fraction was low. Six et al. (2004) postulated that tillage disturbance inhibits stable microaggregate formation within MA and that this does not happen under NT. However, for Mollisols of the Southeastern Argentinean Pampas, there was no difference among cropping systems in MI stability (Table 4) even when comparing PP (Table 2) vs. 100CT (Table 2). 
T A B L E 4 Change of aggregate fraction masses by sieving after two aggregate re-wetting procedures under different cropping systems at three soil depths

\begin{tabular}{|c|c|c|c|c|c|}
\hline \multirow{3}{*}{$\begin{array}{l}\text { Depth } \\
\text { cm }\end{array}$} & \multirow{3}{*}{ Cropping system $^{a}$} & \multicolumn{4}{|c|}{ Change of aggregate fractions mass } \\
\hline & & \multicolumn{4}{|c|}{ Aggregate fraction size } \\
\hline & & $>2.00 \mathrm{~mm}$ & $2.00-0.25 \mathrm{~mm}$ & $0.25-0.05 \mathrm{~mm}$ & $<0.05 \mathrm{~mm}$ \\
\hline \multirow[t]{5}{*}{$0-5$} & PP & $-22.5(1.6)^{b} a^{c}$ & $5.4(1.8) \mathrm{ab}$ & $12.0(2.0) \mathrm{d}$ & $3.8(1.4) \mathrm{a}$ \\
\hline & $50 \mathrm{NT}$ & $-22.5(0.3) \mathrm{a}$ & $8.3(2.6) \mathrm{ab}$ & $10.8(2.0) \mathrm{d}$ & $3.4(1.2) \mathrm{a}$ \\
\hline & $75 \mathrm{CT}$ & $-35.5(1.5) \mathrm{c}$ & 2.9 (2.4)ab & $32.0(1.7) \mathrm{b}$ & $0.6(0.7) \mathrm{a}$ \\
\hline & $100 \mathrm{NT}$ & $-27.5(1.3) \mathrm{ab}$ & $-1.6(0.3) \mathrm{ab}$ & $27.1(3.2) \mathrm{bc}$ & $1.9(2.6) \mathrm{a}$ \\
\hline & $100 \mathrm{CT}$ & $-30.6(1.4) b c$ & $-13.7(0.5) \mathrm{c}$ & $43.2(0.6) \mathrm{a}$ & $1.1(0.4) \mathrm{a}$ \\
\hline \multirow[t]{4}{*}{$5-20$} & PP & $-28.4(1.9) \mathrm{a}$ & $9.7(2.1) \mathrm{a}$ & $17.6(1.8) \mathrm{d}$ & $0.8(0.8) \mathrm{a}$ \\
\hline & $75 \mathrm{CT}$ & $-37.7(2.0) a b$ & $1.5(1.8) \mathrm{a}$ & $31.0(2.2) \mathrm{bc}$ & $5.3(2.2) \mathrm{a}$ \\
\hline & $100 \mathrm{NT}$ & $-34.9(2.3) \mathrm{ab}$ & $6.8(4.6) \mathrm{a}$ & $27.6(2.1) \mathrm{bcd}$ & $0.6(0.5) \mathrm{a}$ \\
\hline & $100 \mathrm{CT}$ & $-42.1(1.6) b$ & $-5.8(1.0) \mathrm{a}$ & $43.6(0.1) \mathrm{a}$ & $6.6(1.4) \mathrm{a}$ \\
\hline \multirow[t]{6}{*}{$0-20$} & $\mathrm{PP}$ & $-26.9(1.5) \mathrm{a}$ & $8.6(1.7) \mathrm{ab}$ & $16.2(1.8) \mathrm{e}$ & $1.5(0.7) \mathrm{a}$ \\
\hline & $50 \mathrm{NT}$ & $-34.9(1.1) b$ & $10.5(3.0) \mathrm{a}$ & $19.8(1.2) \mathrm{de}$ & $4.6(1.5) \mathrm{a}$ \\
\hline & $50 \mathrm{CT}$ & $-33.3(0.6) a b$ & $-3.9(1.4) b c$ & $35.4(1.5) \mathrm{ab}$ & $1.8(1.7) \mathrm{a}$ \\
\hline & $75 \mathrm{NT}$ & $-33.0(1.7) \mathrm{ab}$ & 3.3 (3.6)abc & $25.0(2.3) \mathrm{cd}$ & $4.5(0.2) \mathrm{a}$ \\
\hline & $75 \mathrm{CT}$ & $-37.1(1.9) \mathrm{b}$ & 1.9 (1.9)abc & $31.3(2.0) b c$ & $4.1(1.8) \mathrm{a}$ \\
\hline & $100 \mathrm{NT}$ & $-33.1(1.8) a b$ & 4.7 (3.4)abc & $27.4(2.4) \mathrm{bcd}$ & $1.0(0.3) \mathrm{a}$ \\
\hline
\end{tabular}

${ }^{a} \mathrm{PP}$, permanent pasture; 50NT, 50\% time (3 yr) under cropping with no-tillage and 50\% (3 yr) under pasture; 50CT, 50\% time (3 yr) under cropping with conventional tillage and 50\% (3 yr) under pasture; 75NT, 75\% time (9 yr) under cropping with no-tillage and $25 \%$ (3 yr) under pasture; 75CT, $75 \%$ time (9 yr) under cropping with conventional tillage and 25\% (3 yr) under pasture; 100NT, continuous cropping under no-tillage; 100CT, continuous cropping under conventional tillage.

${ }^{b}$ Numbers in parentheses are standard errors of the mean.

${ }^{\mathrm{c}}$ Values followed by a common letter within each depth are not significantly different $(P<.05)$ among cropping systems.

This looks like Mollisols with loam texture and high and stable original organic matter content like those studied in this work, show mechanisms of aggregate re-cycling and stabilization somehow different from those recognized internationally (Six et al., 2004). Consequently, the difference observed in the proportion of MI between sievings was mainly due to differences in MA disruption with little participation of MI breaking off.

Table 4 shows that changes in the mass of MA (i.e., both small MA and L-MA) were very different. The difference of remnant mass of small MA between sieving after rapid rewetting and after CR was low at all three depths and apparently not related to cropping systems. On the average, after CR small MA represented approximately $30 \%$ of bulk-soil mass at all three depths, whereas, after rapid re-wetting, the proportion of small MA was approximately $32 \%$. However, the difference in remnant mass of L-MA between sievings was much higher (Table 4). On the average, after CR L-MA represented $49 \%$ of bulk-soil mass at all three depths, whereas after rapid re-wetting they represented only $23.4 \pm 3.3 \%, 11.2 \pm$ $2.0 \%$, and $14.2 \pm 2.2 \%$, respectively. Roldán et al. (2014) reported that, during sieving, small MA both receive material from L-MA disruption and provide material to MI due to their own breaking off. This makes difficult to analyze the role of small MA in defining bulk-soil AS and, therefore, changes in L-MA mass appears as more important in defining it. So, it would be appropriate considering either L-MA or MA (i.e., L$\mathrm{MA}+$ small MA) mass changes to characterize bulk-soil AS.

Figure 3 shows MA (L-MA+small MA) mass decrease between sieving after rapid re-wetting and after CR. Change of MA mass between sievings shows the effect of cropping systems on MA stability. As expected, MA mass decrease under PP (Table 2) was significantly lower than the change under most of the other cropping systems at all three depths, whereas the highest MA mass change was observed under 100CT (Table 2). Macroaggregate mass change between sievings under 50NT did not statistically differ from PP and, at the same time, did not differ from 75NT and 100NT except 


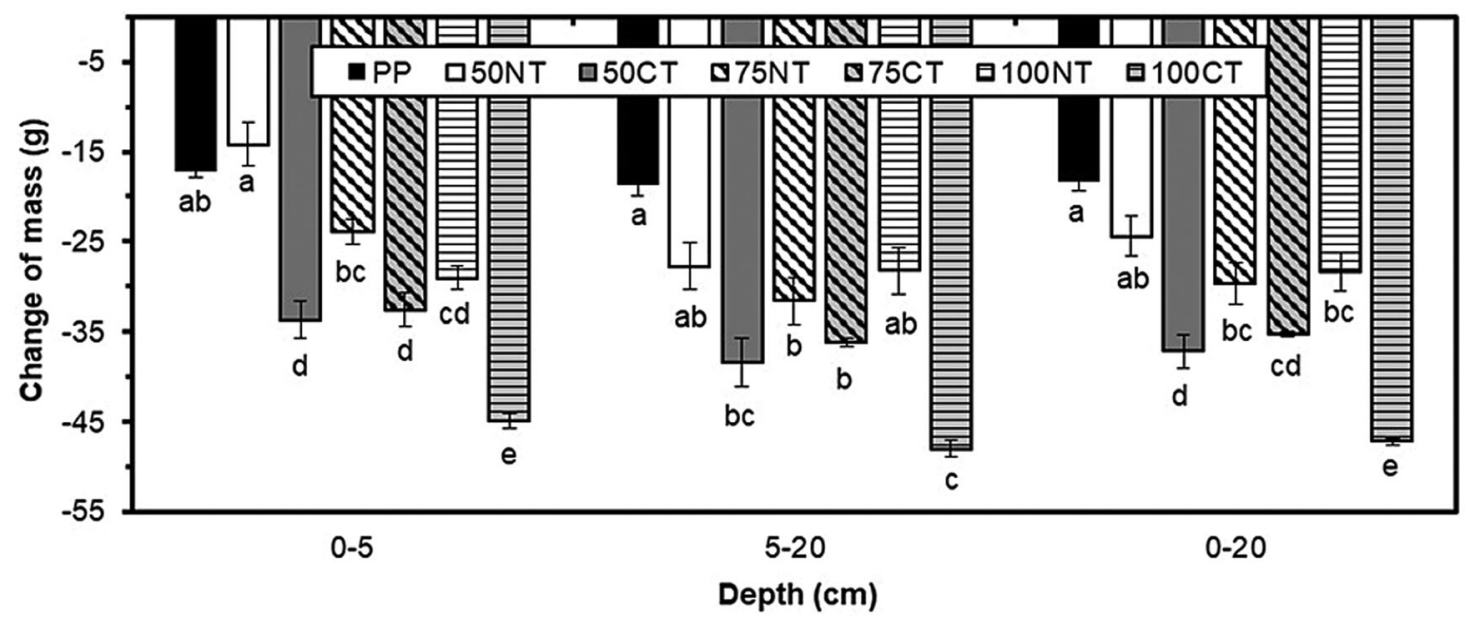

F I G U R E 3 Change of mass of macroaggregates $(>0.25 \mathrm{~mm})$ between sieving after rapid re-wetting and after capillary re-wetting for each cropping system and three soil depths. Vertical bars in each column indicate standard error of the mean. Different letters within soil depth indicate significant differences $(P<.05)$ among cropping systems. PP, permanent pasture; 50NT, 50\% time (3 yr) under cropping with no-tillage and 50\% (3 yr) under pasture; 50CT, 50\% time (3 yr) under cropping with conventional tillage and 50\% (3 yr) under pasture; 75NT, 75\% time (9 yr) under cropping with no-tillage and 25\% (3 yr) under pasture; 75CT, 75\% time (9 yr) under cropping with conventional tillage and $25 \%$ (3 yr) under pasture; $100 \mathrm{NT}$, continuous cropping under no-tillage; 100CT, continuous cropping under conventional tillage

at $0-5 \mathrm{~cm}$ depth. Crop-pasture rotation under $\mathrm{CT}$ showed significantly lower MA mass change than 100CT confirming the beneficial effects of a pasture in the rotation. However, $2 \mathrm{yr}$ under pasture after $3 \mathrm{yr}$ of cropping under CT (i.e., 50CT, Table 2) were not enough to recover MA stability as reported by Studdert et al. (1997), since MA mass change under 50CT was not different from 75CT (Table 2).

Correlation coefficients between CMWD (Figure 2c) and change of MA mass $(P<.01)$ (Figure 3$)$ and change of L-MA mass $(P<.01)$ (Table 4$)$ were $0.88,0.79$, and 0.85 at $0-5,5-$ 20 , and $0-20 \mathrm{~cm}$ depths, respectively, for MA, and 0.96, 0.95, and 0.96 , respectively, for L-MA. This confirms that bulk-soil AS is highly determined by MA stability, especially by the stability of L-MA. It has been proposed that MA instability (i.e., change of mass between sievings) is directly or indirectly related to their organic matter content change, especially to the decrease of labile fractions content (Sheehy et al., 2015; Six et al., 1998, 2004). Therefore, SOC and POC contents and AN within MA or L-MA would be more sensitive than those of bulk soil to indicate early changes in bulk-soil AS (Roldán et al., 2014; Six et al., 2004).

\section{3 | Macroaggregate SOC and POC contents and $\mathrm{AN}$}

It has been reported that MA stability is higher as OC concentration within them is higher ( $\mathrm{Li}$ et al., 2016; Six et al., 2004). Tillage breaks aggregates and inhibits the inclusion and/or persistence of POC within MA leading to stability reduction (Six et al., 2004). The more stable MA show higher POC concentration than those less stable, and this is observed particularly under reduced tillage (i.e., NT) (Sheehy et al., 2015).

Table 5 shows SOC and POC contents of L-MA and MA. As mentioned for bulk-soil SOC and POC contents (Table 3), under pasture SOC and POC in L-MA and MA were, in general, higher than under cropping, although not always significantly. Exudation and decomposition of pasture dense root systems stimulate the activity of mycorrhizae formation fungi. These fungi contribute to aggregate stabilization through the production of glomalin that stabilizes MI that, in turn, are agglutinated within MA by fungi hyphae, rootlets, and polysaccharides from root exudate degradation (Cates et al., 2016; Six et al., 2004). Anyway, as mentioned before, a 2-yr pasture after $3 \mathrm{yr}$ of cropping (i.e., 50NT, and 50CT, Table 2) was not enough to recover SOC and POC in L-MA and MA up to PP level. Continuous pasture showed, in general, significantly higher SOC and POC in L-MA and MA than 50NT and 50CT (Table 5). Likewise, under cropping (i.e., $75 \mathrm{NT}, 75 \mathrm{CT}, 100 \mathrm{NT}$, and $100 \mathrm{CT}$, Table 2), treatments under NT tended to show higher SOC and POC in L-MA and MA than treatments under CT (Table 5). However, the significance of differences among cropping systems both under pasture and under cropping was not as clear as those shown in Table 3. Soil OC and POC contents in L-MA and MA (Table 5) strongly correlated $(P<.01)$ with bulk-soil SOC and POC contents (Table 3) with $\mathrm{r}$ ranging between 0.86 and $0.96,0.61$ and 0.87 , and 0.81 and 0.91 for $0-5,5-20$, and $0-20 \mathrm{~cm}$ depths, respectively. 
T A B L E 5 Total (SOC) and particulate (POC) organic carbon contents of large and total (large + small) macroaggregates at three depths and under different cropping systems. Organic carbon content is expressed in grams of carbon per kilogram of dry aggregate fraction

\begin{tabular}{|c|c|c|c|c|c|}
\hline \multirow{3}{*}{$\begin{array}{l}\text { Depth } \\
\text { cm }\end{array}$} & \multirow[b]{3}{*}{ Cropping system $^{a}$} & \multicolumn{2}{|c|}{ Large macroaggregates } & \multicolumn{2}{|c|}{ Total macroaggregates } \\
\hline & & SOC & POC & SOC & POC \\
\hline & & \multicolumn{4}{|l|}{$\mathrm{g} \mathrm{kg}^{-1}$} \\
\hline \multirow{4}{*}{$0-5$} & $50 \mathrm{NT}$ & $35.2(0.2) \mathrm{b}$ & $13.2(0.7) \mathrm{ab}$ & $36.7(0.2) b$ & $14.5(0.3) \mathrm{b}$ \\
\hline & $50 \mathrm{CT}$ & $32.7(0.4) \mathrm{c}$ & $10.2(0.4) b c$ & $33.2(0.6) \mathrm{c}$ & $10.6(0.4) \mathrm{c}$ \\
\hline & $100 \mathrm{NT}$ & $32.3(0.3) \mathrm{c}$ & $9.0(0.5) \mathrm{c}$ & $33.2(0.5) \mathrm{c}$ & $10.9(0.5) \mathrm{c}$ \\
\hline & $100 \mathrm{CT}$ & $28.2(0.6) \mathrm{d}$ & $7.0(0.5) \mathrm{c}$ & $29.1(0.5) \mathrm{d}$ & $8.7(0.4) \mathrm{cd}$ \\
\hline \multirow[t]{4}{*}{$5-20$} & $\mathrm{PP}$ & $32.2(0.4) \mathrm{a}$ & $12.1(0.5) \mathrm{a}$ & $32.1(0.7) \mathrm{a}$ & $12.2(0.8) \mathrm{a}$ \\
\hline & $50 \mathrm{NT}$ & $29.0(0.4) \mathrm{ab}$ & $9.4(0.4) \mathrm{ab}$ & $29.1(0.7) \mathrm{ab}$ & $9.0(0.6) \mathrm{b}$ \\
\hline & $100 \mathrm{NT}$ & $26.9(0.6) b$ & $7.9(0.6) b c$ & $27.5(0.6) b$ & $8.2(0.7) b c$ \\
\hline & $100 \mathrm{CT}$ & $27.2(0.8) b$ & $5.6(0.9) \mathrm{c}$ & $27.5(0.6) b$ & $6.2(0.6) \mathrm{c}$ \\
\hline \multirow[t]{7}{*}{$0-20$} & PP & $33.8(0.4) \mathrm{a}$ & $13.0(0.5) \mathrm{a}$ & $34.0(0.7) \mathrm{a}$ & $13.4(0.7) \mathrm{a}$ \\
\hline & $50 \mathrm{NT}$ & $30.6(0.3) \mathrm{b}$ & $10.3(0.3) \mathrm{bc}$ & $31.1(0.5) \mathrm{ab}$ & $10.4(0.4) \mathrm{b}$ \\
\hline & $50 \mathrm{CT}$ & $30.2(0.7) b c$ & $8.6(0.2) \mathrm{cd}$ & $30.9(0.9) \mathrm{ab}$ & $8.9(0.5) b c$ \\
\hline & $75 \mathrm{NT}$ & $30.5(1.1) \mathrm{b}$ & $11.1(0.7) \mathrm{ab}$ & $30.2(1.0) \mathrm{b}$ & $9.5(0.8) b c$ \\
\hline & $75 \mathrm{CT}$ & $28.4(0.2) b c$ & $7.4(0.3) \mathrm{de}$ & $28.6(0.7) \mathrm{b}$ & $7.9(0.1) \mathrm{cd}$ \\
\hline & $100 \mathrm{NT}$ & $28.2(0.3) b c$ & $8.2(0.4) \mathrm{cde}$ & $29.0(0.3) \mathrm{b}$ & $9.0(0.4) b c$ \\
\hline & $100 \mathrm{CT}$ & $27.4(0.7) \mathrm{c}$ & $5.9(0.7) \mathrm{e}$ & $27.9(0.6) \mathrm{b}$ & $6.8(0.4) \mathrm{d}$ \\
\hline
\end{tabular}

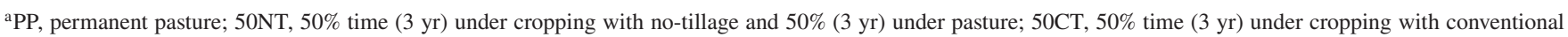
tillage and 50\% (3 yr) under pasture; 75NT, 75\% time (9 yr) under cropping with no-tillage and $25 \%$ (3 yr) under pasture; $75 \mathrm{CT}, 75 \%$ time $(9 \mathrm{yr})$ under cropping with conventional tillage and 25\% (3 yr) under pasture; 100NT, continuous cropping under no-tillage; 100CT, continuous cropping under conventional tillage.

${ }^{\mathrm{b}}$ Numbers in parentheses are standard errors of the mean.

${ }^{c}$ Values followed by a common letter within each depth are not significantly different $(P<.05)$ among cropping systems.

Figure 4 shows AN in L-MA and MA as a function of cropping system and depth. Differences among cropping systems at all three depths showed similar trends as for bulk-soil AN (Table 3) and, in general, consistent with L-MA and MA SOC and POC contents (Table 5). Both L-MA and MA AN strongly correlated with bulk-soil AN $(P<.01)$ at all three depths ( $\mathrm{r}$ ranging between 0.64 and 0.77 ). As already shown for bulk-soil (Table 3), under pasture (i.e., PP, 50NT, and 50CT, Table 2) L-MA and MA AN were higher than under cropping (i.e., $75 \mathrm{NT}, 75 \mathrm{CT}, 100 \mathrm{NT}$, and $100 \mathrm{CT}$, Table 2) (Figure 4). Likewise, under NT L-MA and MA AN were higher than under CT. In general, cropping systems under NT showed significantly higher AN than the corresponding cropping system under CT (i.e., $50 \mathrm{NT}$ vs. $50 \mathrm{CT}$, $75 \mathrm{NT}$ vs. $75 \mathrm{CT}$, and $100 \mathrm{NT}$ vs. 100CT). It is worth noting that both L-MA and MA AN, as well as bulk-soil AN (Table 3), showed clearly the effect of the increasing ecological agriculture intensification (i.e., increase of frequency of pastures in the rotation: $100 \mathrm{NT}=100 \mathrm{CT}<75 \mathrm{NT}=75 \mathrm{CT}<50 \mathrm{NT}=50 \mathrm{CT}<\mathrm{PP}$,
Table 2) on the variation of AN in both L-MA and MA (Figure 4).

\subsection{Nitrogen mineralized in anaerobiosis and aggregate stability}

Domínguez et al. (2016) showed that change of CMWD due to tillage system along cropping periods could be explained by the variation in bulk-soil SOC and POC. In our experiment, CMWD strongly correlated with both bulk-soil SOC and POC contents and L-MA and MA SOC and POC contents (Table 6). This correlation was particularly strong at 0-5 and 0-20 cm depths as also reported by Domínguez et al. (2016). Changes in bulk-soil SOC and POC contents due to the cropping system (Table 3 ) is reflected in variations in AS (Domínguez et al., 2016; Sheehy et al., 2015). Likewise, the correlations between both L-MA and MA SOC and POC contents and CMWD were also high, especially at $0-5$ and 

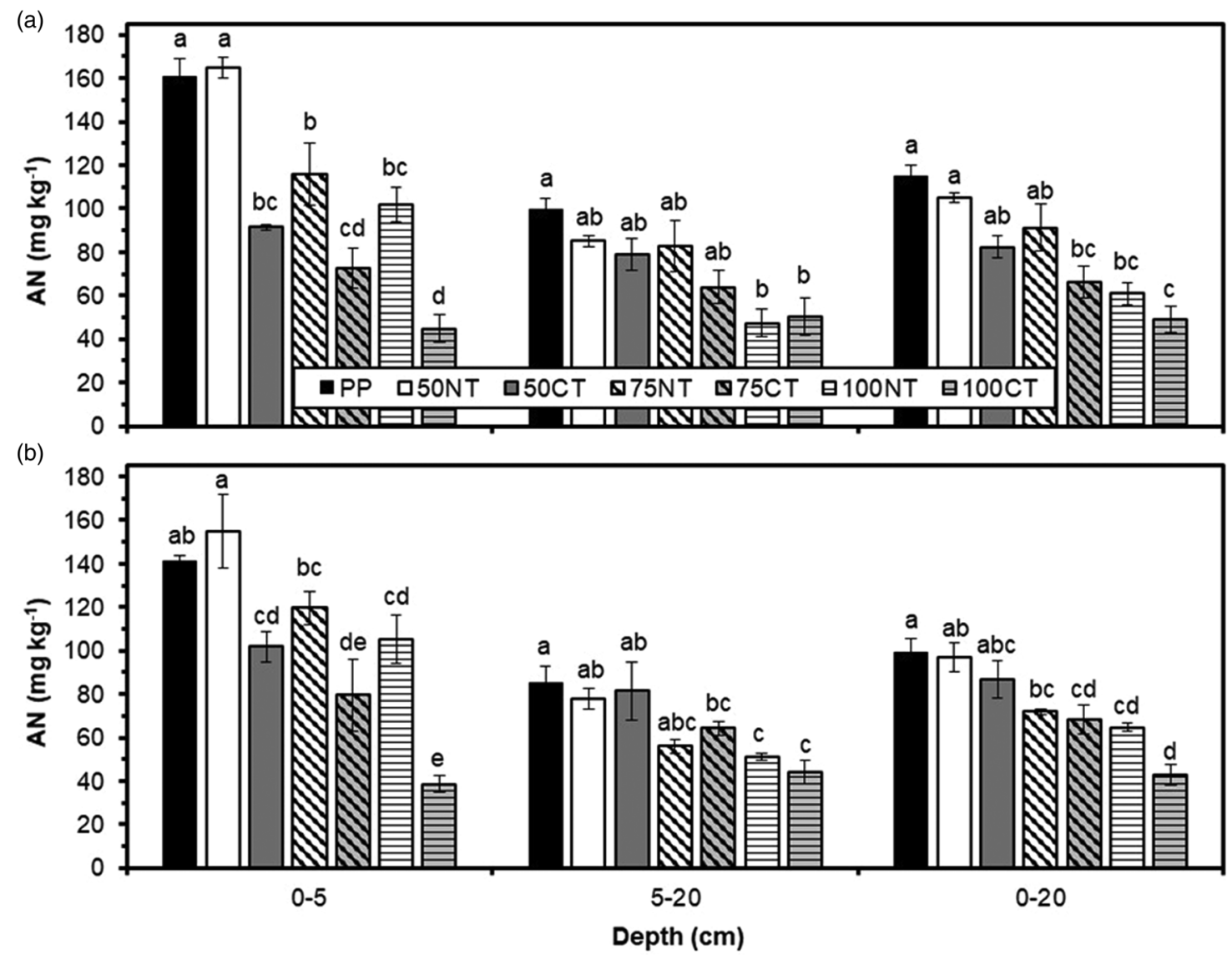

F I G U R E 4 Large (a) and total macroaggregate (large + small) (b) nitrogen mineralized in anaerobiosis (AN) at three depths under different cropping systems. Vertical bars in each column indicate standard error of the mean. Different letters within soil depth indicate significant differences $(P<.05)$ among cropping systems. PP, permanent pasture; 50NT, 50\% time (3 yr) under cropping with no-tillage and 50\% (3 yr) under pasture; 50CT, 50\% time (3 yr) under cropping with conventional tillage and 50\% (3 yr) under pasture; 75NT, 75\% time (9 yr) under cropping with no-tillage and 25\% (3 yr) under pasture; 75CT, 75\% time (9 yr) under cropping with conventional tillage and 25\% (3 yr) under pasture; 100NT, continuous cropping under no-tillage; $100 \mathrm{CT}$, continuous cropping under conventional tillage

0-20 cm depths (Table 6). Cozzoli et al. (2010) had also reported a high correlation between MA SOC and POC contents and AS of similar soils under different cropping systems. It is worth pointing out that those authors used a different method to separate MA (dry sieving).

Domínguez et al. (2016) proposed that AN could be a good indicator of CMWD since changes of AS were satisfactorily explained by the variation in bulk-soil AN. Even though AN per se is not directly responsible of aggregation and AS, it is highly related to SOC and POC. Therefore, AN level reflects the change of those organic fractions more directly responsible of aggregate formation and stabilization (Domínguez et al., 2016; Six et al., 2004; Studdert et al., 2017). Cropping systems lead to changes of aggregate forming organic agents (i.e., particulate organic matter, fungi hyphae, and root carbohydrates within MA) (Six et al., 2004) and, therefore, affect AS (Cates et al., 2016) (Table 4; Ernst \& Siri-Prieto, 2009; Six et al., 2004; Studdert et al., 1997). In our experiment, it has been demonstrated that bulk-soil AN strongly correlated with bulk-soil SOC and POC (Table 3). Likewise, it was demonstrated that bulk-soil AN strongly correlates with CMWD (Table 6). Figure 5a, b, c shows that bulk-soil AN variation explained 75, 41, and 71\% of CMWD variation at $0-5,5-20$, and 0-20 cm depths, respectively. Similar results had been reported by Domínguez et al. (2016) for similar soils under different cropping systems. Therefore, routine determinations of bulk-soil AN done by farmers to diagnose soil N fertility (Orcellet et al., 2017; Reussi-Calvo et al., 2013, 2018) would also provide valuable information about soil AS status. This confirms that AN could be used as a soil health indicator (Domínguez et al., 2016; García et al., 2016; Soon et al., 2007).

Bulk-soil AS is mainly associated with MA stability (Roldán et al., 2014; Sheehy et al., 2015; Six et al., 2004). Changes the in mass of L-MA (Table 4) and of MA (Figure 3) strongly correlated with CMWD (Figure 2c). Given the strong correlations between L-MA and MA SOC and POC contents and CMWD (Table 6) and between the 
T A B L E 6 Correlation between change of mean weight aggregate diameter and soil (SOC) and particulate (POC) organic carbon, and ammonium nitrogen mineralized in anaerobiosis (AN) of bulk soil (BS), large macroaggregates (L-MA, >2.00 mm) and total macroaggregates $($ small + large $)(\mathrm{MA},>0.25 \mathrm{~mm})$ at three depths. All correlations are highly significant $(P<.01, n=21)$

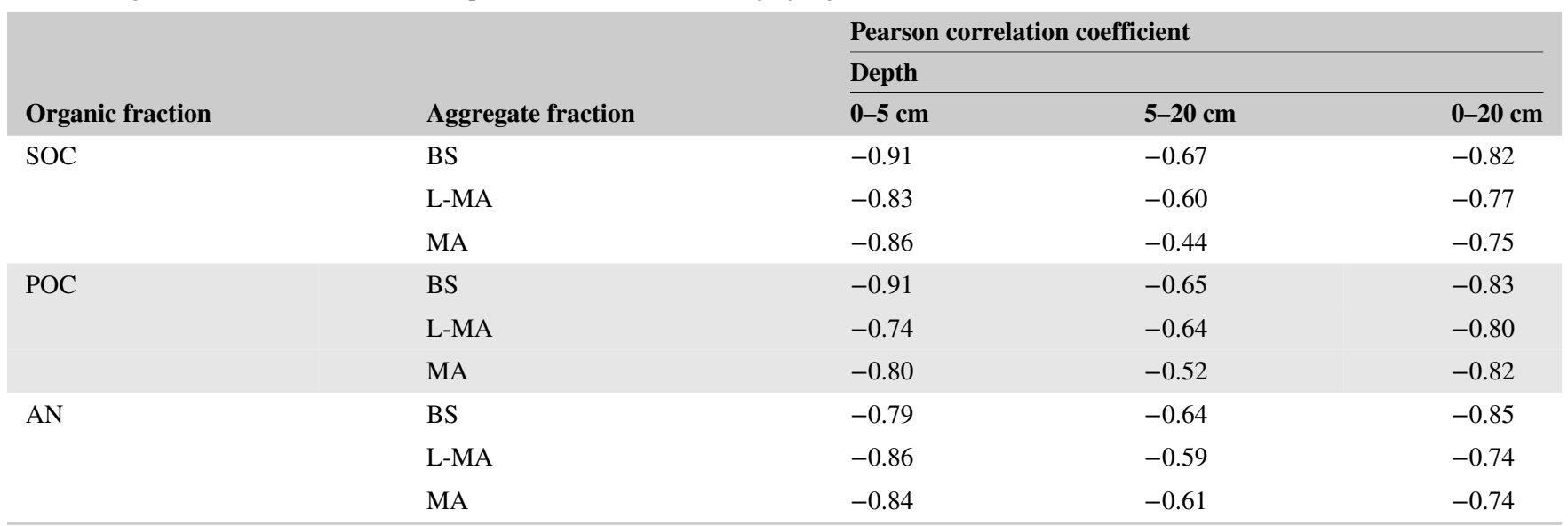
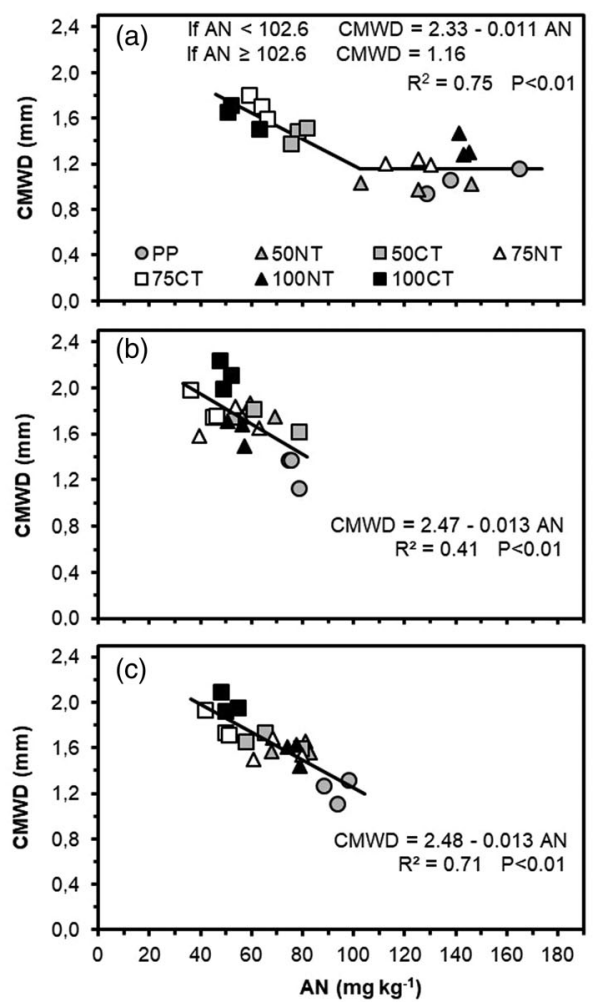
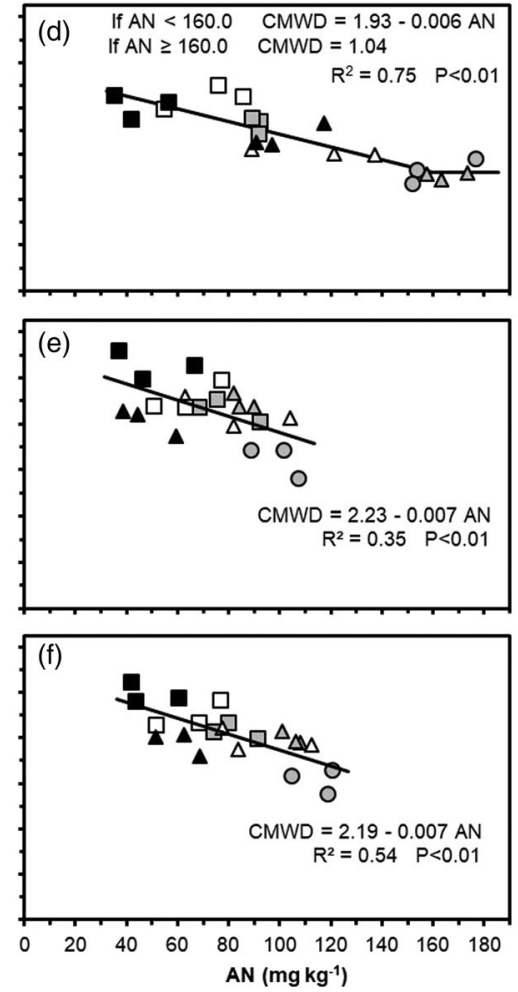
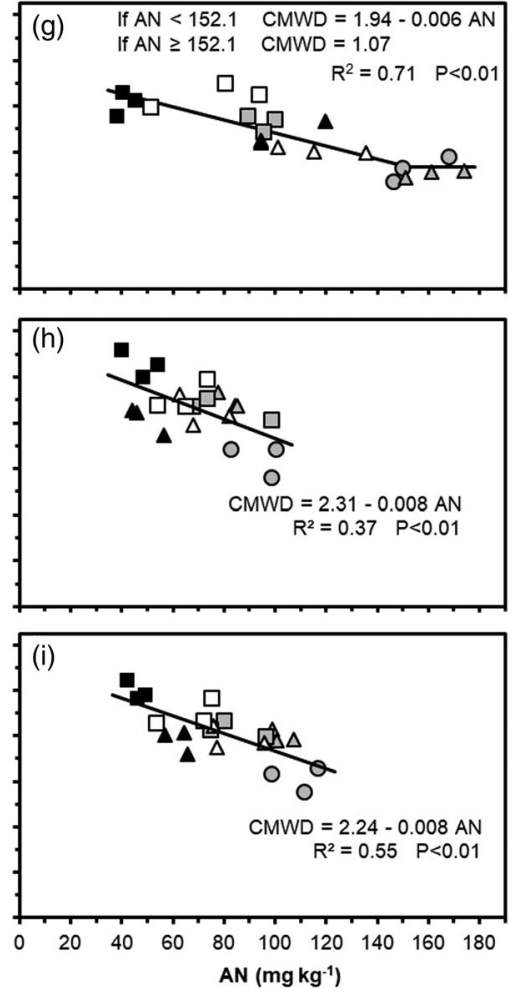

F I G U R E 5 Change of mean weight aggregate diameter (CMWD) as a function of bulk soil (a, b, c), large macroaggregate (>2.00 mm) (d, e, f), and total macroaggregate (large + small, $>0.25 \mathrm{~mm})(\mathrm{g}, \mathrm{h}, \mathrm{i})$ nitrogen mineralized in anaerobiosis (AN) at threes depths: $0-5 \mathrm{~cm}(\mathrm{a}, \mathrm{d}, \mathrm{g}$ ), 5-20 cm (b, e, h), and 0-20 cm (c, f, i). PP, permanent pasture; 50NT, 50\% time (3 yr) under cropping with no-tillage and 50\% (3 yr) under pasture; 50CT, 50\% time ( $3 \mathrm{yr}$ ) under cropping with conventional tillage and 50\% (3 yr) under pasture; 75NT, 75\% time (9 yr) under cropping with no-tillage and $25 \%$ ( $3 \mathrm{yr}$ ) under pasture; 75CT, 75\% time (9 yr) under cropping with conventional tillage and 25\% (3 yr) under pasture; 100NT, continuous cropping under no-tillage; $100 \mathrm{CT}$, continuous cropping under conventional tillage

formers and L-MA and MA AN, respectively, high association between the latters and CMWD could be expected. Table 6 shows that correlation coefficients between L-MA and CMWD and MA AN and CMWD were high and close to correlation coefficients between bulk-soil AN and CMWD.
However, changes in CMWD due to the cropping system were not as highly explained by L-MA AN (Figure 5d, e, f) or MA AN (Figure $5 \mathrm{~g}, \mathrm{~h}, \mathrm{i}$ ) variations as by bulk-soil AN (Figure 5a, b, c) except at 0-5 cm depth (Figure 5d, g). Likewise, slopes of linear regressions describing the relationships between 
CMWD and bulk-soil AN were between $63 \%$ and $84 \%$ higher than those of CMWD on L-MA AN and of CMWD on MA AN (Figure 5). Hence, for each unit change of bulk-soil AN, CMWD changed much more than for each unit change of L-MA or MA AN. Therefore, changes in bulk-soil AN due to soil use describe AS changes produced by management practices with higher sensitiveness. When water-sieving to separate aggregates, part of organic labile fractions (fungi hyphae, rootlets, free inter-aggregate POC, polysaccharides) that contribute to both bulk-soil AS and to bulk-soil AN (Cates et al., 2016; Six et al., 2004), are removed in solution or suspension with discarded water and/or associated to the fractions do not considered in this study (i.e., MI and fine fraction). Therefore, their contribution to $\mathrm{AN}$ is considered when analyzing bulk soil, but not when analyzing L-MA or MA. When expressed respect to dry aggregate mass, L-MA AN and MA AN were higher than bulk-soil AN (Table 5). Though, when L-MA AN was expressed respect to bulk-soil dry mass (on the average, $58.4 \pm 31.8 \mathrm{mg} \mathrm{kg}^{-1}, 34.9 \pm 13.3 \mathrm{mg}$ $\mathrm{kg}^{-1}$, and $40.3 \pm 16.7 \mathrm{mg} \mathrm{kg}^{-1}$ at $0-5,5-20$, and $0-20 \mathrm{~cm}$ depths, respectively), it represented only between $56 \%$ and $61 \%$ of bulk-soil AN. On the other hand, MA AN expressed respect to bulk-soil dry mass (on the average, $89.1 \pm 41.3 \mathrm{mg}$ $\mathrm{kg}^{-1}, 55.6 \pm 18.7 \mathrm{mg} \mathrm{kg}^{-1}$, and $63.8 \pm 23.1 \mathrm{mg} \mathrm{kg}^{-1}$ at 0-5, 5-20, and 0-20 cm, respectively) represented between $85 \%$ and $97 \%$ of bulk-soil AN. Therefore, even though MA $\mathrm{AN}$ represented a very high proportion of bulk-soil $\mathrm{AN}$, the part of AN discarded along the sieving process does play an important role in characterizing CMWD as a function of AN.

\section{4 | CONCLUSIONS}

Cropping systems evaluated did generate differences in SOC, POC, AN, and AS. Evidence collected was not enough to reject the first hypothesis given changes in bulk-soil AN adequately described changes in soil AS in the arable layer. Therefore, bulk-soil AN could be used as an indicator of AS. Determination of bulk-soil AN at 0-20 cm depth has been proposed as an important tool to help to diagnose soil capacity to supply $\mathrm{N}$ to crops along their growing season. Therefore, these findings make the determination of bulk-soil AN also valuable to have an early indication of soil AS status. On the other hand, the evidence collected lead to rejecting the second hypothesis. Even though AN from L-MA or MA was as strongly related to changes in bulk-soil AS as bulk-soil AN, their performance as predictors of CMWD was poorer. This means it is no worth doing additional work to separate MA and then determine their AN.

The results of this work confirm previous results but both studies were done on the same Mollisols with loam texture and high organic matter content. To confirm the benefits of our findings it is necessary to evaluate the relationship between bulk-soil AN and soil AS in a broader range of textures and management practices.

\section{ACKNOWLEDGMENTS}

This work is part of the Undergraduate Thesis of the Senior author (career of Ingeniería Agronómica) and part of the Doctoral Dissertation of the second author (Programa de Posgrado en Ciencias Agrarias), at the Facultad de Ciencias Agrarias, Universidad Nacional de Mar del Plata, Argentina. The Senior author has been granted a fellowship from the Consejo Nacional de Investigaciones Científicas y Técnicas. The third author has been granted a fellowship from the Comisión de Investigaciones Científicas de la Provincia de Buenos Aires. This work has been supported by the Fondo para la Investigación Científica y Tecnológica (PICT 2012-1092), the Universidad Nacional de Mar del Plata (AGR537/17 and AGR570/18), and the Instituto Nacional de Tecnología Agropecuaria (PNCyO 1127032), Argentina.

\section{ORCID}

Guillermo A. Studdert (iD

https://orcid.org/0000-0002-8611-4441

\section{REFERENCES}

Aparicio, V., \& Costa, J. (2007). Soil quality indicators under continuous cropping systems in the Argentinean Pampas. Soil and Tillage Research, 96, 155-165. https://doi.org/10.1016/j.still.2007.05.006

Cambardella, C., \& Elliott, E. (1992). Particulate soil organic matter. Changes across a grassland cultivation sequence. Soil Science Society of America Journal, 56, 777-783. https://doi.org/10.2136/ sssaj1992.03615995005600030017x

Cambardella, C., \& Elliott, E. (1993). Carbon and nitrogen distribution in aggregates from cultivated and native grassland soils. Soil Science Society of America Journal, 57, 1071-1076. https://doi.org/ 10.2136/sssaj1993.03615995005700040032x

Cates, A., Ruark, M., Hudtcke, J., \& Posner, J. (2016). Long-term tillage, rotation and perennialization effects on particulate and aggregate soil organic matter. Soil and Tillage Research, 155, 371-380. https://doi.org/10.1016/j.still.2015.09.008

Caviglia, O. P., Rizzalli, R. H., Monzón, J. P., García, F. O., Melchiori, R. J. M., Cerrudo, A., ... Andrade, F. H. (2019). Improving resource productivity at a crop sequence level. Field Crops Research, 235, 129-141. https://doi.org/10.1016/j.fcr.2019.02.011

Christensen, B. (2001). Physical fractionation of soil and structural and functional complexity in organic matter turnover. European Journal of Soil Science, 52, 345-353. https://doi.org/10.1046/ j.1365-2389.2001.00417.x

Cozzoli, M. V., Fioriti, N., Studdert, G. A., Domínguez, G. F., \& Eiza, M. J. (2010). Nitrógeno liberado por incubación anaeróbica y fracciones de carbono en macro- y microagregados bajo distintos sistemas de cultivo. Cuidado del Suelo, 28, 155-167.

Diovisalvi, N. V., Studdert, G. A., Reussi-Calvo, N., Domínguez, G. F., \& Berardo, A. (2014). Estimating soil particulate organic carbon through total soil organic carbon content. Cuidado del Suelo, 32, 85-94. 
Domínguez, G. F., Diovisalvi, N. V., Studdert, G. A., \& Monterubbianesi, M. G. (2009). Soil organic C and N fractions under continuous cropping with contrasting tillage systems on Mollisols of the Southeastern Pampas. Soil Tillage Research, 102, 93-100. https://doi.org/10.1016/j.still. 2008.07.020

Domínguez, G. F., García, G. V., Studdert, G. A., Agostini, M. A., Tourn, S. N., \& Domingo, M. N. (2016). Is anaerobic mineralizable nitrogen suitable as soil health indicator? Spanish Journal of Soil Science, 6, 82-97. https://doi.org/10.3232/SJSS.2016.V6.N2.01

Doran, J. W. (2002). Soil health and global sustainability: Translating science into practice. Agriculture, Ecosystems \& Environment, 88, 119-127. https://doi.org/10.1016/S0167-8809(01)00246-8

Echeverría, H. E., San Martín, N. F., \& Bergonzi, R. (2000). Métodos rápidos de estimación de nitrógeno potencialmente mineralizable en suelos. Cuidado del Suelo, 18, 9-16.

Ernst, O., \& Siri-Prieto, G. (2009). Impact of perennial pasture and tillage systems on carbon input and soil quality indicators. Soil and Tillage Research, 105, 260-268. https://doi.org/10.1016/ j.still.2009.08.001

Ernst, O. R., Dogliotti, S., Cadenazzi, M., \& Kemanian, A. R. (2018). Shifting crop-pasture rotations to no-till annual cropping reduces soil quality and wheat yield. Field Crops Research, 217, 180-187. https://doi.org/10.1016/j.fcr.2017.11.014

Franzluebbers, A., Sawchik, J., \& Taboada, M. (2014). Agronomic and environmental impacts of pasture-crop rotation in temperate North and South America. Agriculture, Ecosystems \& Environment, 190, 18-26. https://doi.org/10.1016/j.agee.2013.09.017

Franzluebbers, A. J. (2002). Soil organic matter stratification ratio as an indicator of soil quality. Soil and Tillage Research, 66, 95-106. https://doi.org/10.1016/S0167-1987(02)00018-1

García, G. V., Studdert, G. A., Domingo, M. N., \& Domínguez, G. F. (2016). Nitrógeno mineralizado en anaerobiosis: Relación con sistemas de cultivo de agricultura continua. Cuidado del Suelo, 34, 127138.

Gregorich, E. G., Beare, M. H., McKim, U. F., \& Skjemstad, J. O. (2006). Chemical and biological characteristics of physically uncomplexed organic matter. Soil Science Society of America Journal, 70, 975985. https://doi.org/10.2136/sssaj2005.0116

Gregorutti, V. C., Novelli, L. E., Melchiori, R. J. M., Ormaechea, M. V., \& Caviglia, O. P. (2014). Nitrógeno incubado en anaerobiosis y su relación con el nitrógeno orgánico en diferentes fracciones. Cuidado del Suelo, 32, 41-51.

Haynes, R. (1999). Labile organic matter fractions and aggregate stability under short-term, grass-based leys. Soil Biology and Biochemistry, 31, 1821-1830. https://doi.org/10.1016/S00380717(99)00102-9

Hochman, Z., Carberry, P. S., Robertson, M. J., Gaydon, D. S., Bell, L. W., \& McIntosh, P. C. (2013). Prospects for ecological intensification of Australian agriculture. European Journal of Agronomy, 44, 109123. https://doi.org/10.1016/j.eja.2011.11.003

Hofman, G., \& de Leenheer, L. (1975). Influence of soil prewetting on aggregate stability. Pedologie (Gent), 25, 190-198.

INTA. (1979). Cartas de suelo de la República Argentina. Hoja 3757-31 Balcarce. Instituto Nacional de Tecnología Agropecuaria. Secretaría de Agricultura de Ganadería y Pesca. Buenos Aires, Argentina.

Keeney, D. R. (1982). Nitrogen-availability indexes. In A. L. Page (Ed.), Methods of soil analysis. Part 2. Chemical and microbiological prop- erties. Agron. Monogr. 9 (pp. 711-733). Madison, WI: ASA and SSSA.

Keeney, D. R., \& Nelson, D. W. (1982). Nitrogen inorganic forms. In A. L. Page (Ed.), Methods of soil analysis. Part 2. Chemical and microbiological properties. Agron. Monogr. 9 (pp. 643-698). Madison, WI: ASA and SSSA.

Lemaire, G., Franzluebbers, A., de Faccio Carvalho, P. C., \& Dedieu, B. (2014). Integrated crop-livestock systems: Strategies to achieve synergy between agricultural production and environmental quality. Agriculture, Ecosystems \& Environment, 190, 4-8. https://doi.org/ 10.1016/j.agee.2013.08.009

Li, S., Gu, X., Zhuang, J., An, T., Pei, J., Xie, H., ... Wang, J. (2016). Distribution and storage of crop residue carbon in aggregates and its contribution to organic carbon of soil with low fertility. Soil and Tillage Research, 155, 199-206. https://doi.org/10.1016/j.still.2015.08.009

Novelli, L. E., Caviglia, O. P., \& Piñeiro, G. (2017). Increased cropping intensity improves crop residue inputs to the soil and aggregateassociated soil organic carbon stocks. Soil and Tillage Research, 165, 128-136. https://doi.org/10.1016/j.still.2016.08.008

Orcellet, J. M., Reussi-Calvo, N. I., Sainz-Rozas, H. R., Wyngaard, W., \& Echeverría, H. E. (2017). Anaerobically incubated nitrogen improved nitrogen diagnosis in corn. Agronomy Journal, 109, 291298. https://doi.org/10.2134/agronj2016.02.0115

Panettieri, M., Berns, A., Knicker, B., Murillo, J., \& Madejón, E. (2015). Evaluation of seasonal variability of soil biogeochemical properties in aggregate-size fractioned soil under different tillages. Soil and Tillage Research, 151, 39-49. https://doi.org/10.1016/ j.still.2015.02.008

Panettieri, M., Rumpel, C., Dignac, M., \& Chabbi, A. (2017). Does grassland introduction into cropping cycles affect carbon dynamics through changes of allocation of soil organic matter within aggregate fractions? Science of The Total Environment, 576, 251-263. https://doi.org/10.1016/j.scitotenv.2016.10.073

Powlson, D., Stirling, C., Jat, M., Gerard, B., Palm, C., Sánchez, P., \& Cassman, K. (2014). Limited potential of no-till agriculture for climate change mitigation. Nature Climate Change, 4, 678-683. https://doi.org/10.1038/nclimate2292

Powlson, D. S., Gregory, P. J., Whalley, W. R., Quinton, J. N., Hopkins, D. W., Whitmore, A. P., ... Goulding, K. W. T. (2011). Soil management in relation to sustainable agriculture and ecosystem services. Food Policy, 36, S72-S87. https://doi.org/10.1016/ j.foodpol.2010.11.025

Puget, P., Chenu, C., \& Balesdent, J. (2000). Dynamics of soil organic matter associated with particle-size fractions of water-stable aggregates. European Journal of Soil Scienc, 51, 595-605. https://doi.org/ 10.1111/j.1365-2389.2000.00353.x

Puget, P., \& Lal, R. (2005). Soil organic carbon and nitrogen in a Mollisol in central Ohio as affected by tillage and land use. Soil and Tillage Research, 80, 201-213. https://doi.org/10.1016/j.still.2004.03.018

Quiroga, R. A., \& Studdert, G. A. (2014). Manejo del suelo e intensificación agrícola: Agua y materia orgánica, dos aspectos clave. In $\mathrm{H}$. E. Echeverría \& F. O. García, (Eds.), Fertilidad de suelos y fertilización de cultivos (2nd ed., pp. 73-100). Buenos Aires, Argentina: Ediciones INTA.

R Development Core Team. (2010). R: A language and environment for statistical computing R Foundation for Statistical Computing, Vienna, Austria. Retrieved from http://www.R-project.org (accessed 10 Jun. 2013). 
Reussi-Calvo, N. I., Sainz-Rozas, H. R., Echeverría, H. E., \& Berardo, A. (2013). Contribution of anaerobically incubated nitrogen to the diagnosis of nitrogen status in spring wheat. Agronomy Journal, 105 , 1-8. https://doi.org/10.2134/agronj2012.0287

Reussi-Calvo, N. I., Studdert, G. A., Calandroni, M. B., Diovisalvi, N. V., Cabria, F. N., \& Berardo, A. (2014). Nitrógeno incubado en anaerobiosis y carbono orgánico en suelos agrícolas de Buenos Aires. Cuidado del Suelo, 32, 189-196.

Reussi-Calvo, N. I., Wyngaard, N., Orcellet, J. M., Sainz-Rozas, H. R., \& Echeverría, H. E. (2018). Predicting field-apparent nitrogen mineralization from anaerobically incubated nitrogen. Soil Science Society of America Journal, 82, 502-508. https://doi.org/10.2136/ sssaj2017.11.0395

Roldán, M., Studdert, G. A., Videla, C. C., San Martino, S., \& Picone, L. I. (2014). Distribución de tamaño y estabilidad de agregados en molisoles bajo labranzas contrastantes. Cuidado del Suelo, 32, 247257.

Romig, D. E., Garlynd, M. J., \& Harris, R. F. (1996). Farmer-based assessment of soil quality: A soil health scorecard. In J. W. Doran \& A. J. Jones (Eds.), Methods for assessing soil quality (pp. 39-60). Madison, WI: SSSA Spec. Publ. 49. SSSA.

Sainz-Rozas, H. R., Calviño, P., Echeverría, H. E., Barbieri, P. A., \& Redolatti, M. (2008). Contribution of anaerobically mineralized nitrogen to the reliability of planting or presidedress soil nitrogen test in maize. Agronomy Journal, 100, 1020-1025. https://doi.org/10.2134/agronj2007.0077

Schlichting, E., Blume, H. P., \& Stahr, K. (1995). Bodenkundliches Praktikum. Hamburg, Germany: Paul Parey

Sheehy, J., Regina, K., Alakukku, L., \& Six, J. (2015). Impact of no-till and reduced tillage on aggregation and aggregate-associated carbon in Northern European agroecosystems. Soil and Tillage Research, 150, 107-113. https://doi.org/10.1016/j.still.2015.01.015

Six, J., Bossuyt, H., Degryze, S., \& Denef, K. (2004). A history of research on the link between (micro) aggregates, soil biota, and soil organic matter dynamics. Soil and Tillage Research, 79, 7-31. https://doi.org/10.1016/j.still.2004.03.008

Six, J., Elliott, E., \& Paustian, K. (2000). Soil macroaggregate turnover and microaggregate formation: A mechanism for $\mathrm{C}$ sequestration under no-tillage agriculture. Soil Biology and Biochemistry, 32, 2099-2103. https://doi.org/10.1016/S0038-0717(00)00179-6
Six, J., Elliott, E., Paustian, K., \& Doran, J. (1998). Aggregation and soil organic matter accumulation in cultivated and native grassland soils. Soil Science Society of America Journal, 62, 1367-1377. https://doi.org/10.2136/sssaj1998.03615995006200050032x

Soil Survey Staff. (2014). Keys to soil taxonomy. Washington, DC: USDA, Natural Resources Conservation Service.

Soon, Y. K., Haq, A., \& Arshad, M. A. (2007). Sensitivity of nitrogen mineralization indicators to crop and soil management. Communications in Soil Science and Plant Analysis, 38, 2029-2043. https://doi.org/10.1080/00103620701548688

Studdert, G. A., Domingo, M. N., García, G. V., Monterubbianesi, M. G., \& Domínguez, G. F. (2017). Carbono orgánico del suelo bajo sistemas de cultivo contrastantes y su relación con la capacidad de proveer nitrógeno. Cuidado del Suelo, 35, 285-300.

Studdert, G. A., Echeverría, H. E., \& Casanovas, E. M. (1997). Croppasture rotation for sustaining the quality and productivity of a typic argiudoll. Soil Science Society of America Journal, 61, 1466-1472. https://doi.org/10.2136/sssaj1997.03615995006100050026x

Triplett, G. B., \& Dick, W. A. (2008). No-tillage crop production: A revolution in agriculture!. Agronomy Journal, 100, S153-S165. https:// doi.org/10.2134/agronj2007.0005c

Videla, C., Pazos, A., Trivelin, P. C., Echeverría, H. E., \& Studdert, G. A. (2005). Mineralización bruta de nitrógeno en un Molisol de Balcarce bajo labranza convencional, siembra directa y pastura. Cuidado del Suelo, 23, 133-144.

Yamashita, T., Flessa, H., John, B., Helfrich, M., \& Ludwig, B. (2006). Organic matter in density fractions of water-stable aggregates in silty soils: Effect of land use. Soil Biology and Biochemistry, 38, 3222-3234.

How to cite this article: Rivero C, Tourn SN, García GV, Videla CC, Domínguez GF, Studdert GA. Nitrogen mineralized in anaerobiosis as indicator of soil aggregate stability. Agronomy Journal. 2020;1-16. https://doi.org/10.1002/agj2.20056 